\title{
Water resource decoupling in the MENA through food trade as a mechanism for circumventing national water scarcity
}

Michael Gilmont 1,*

Email michael.gilmont@ouce.ox.ac.uk

Michael Gilmont is a Research Fellow in the Global Assessment of Water Security at the Environmental Change Institute, Oxford, investigating relationships between economic growth, hydroclimatic vulnerability and water infrastructure investments. His analysis focuses on comparing trajectories of states in India. He is also working on water development investments and transboundary water relationships in Asia and Africa, with particular focus on China. Michael completed his PhD at King's College London on the politics of water reform and the processes of bridging often conflicting demands of social, economic/agricultural and environmental water needs in neoliberal political economies (Israel, California, S.E. Australia). Michael maintains an active interest in water governance and policy reform, along with ongoing work on the decoupling of national economic and population growth from water resource use in water-scarce economies. He holds a BA in Geography (Cambridge) and an MSc in Hydrology (Imperial College).

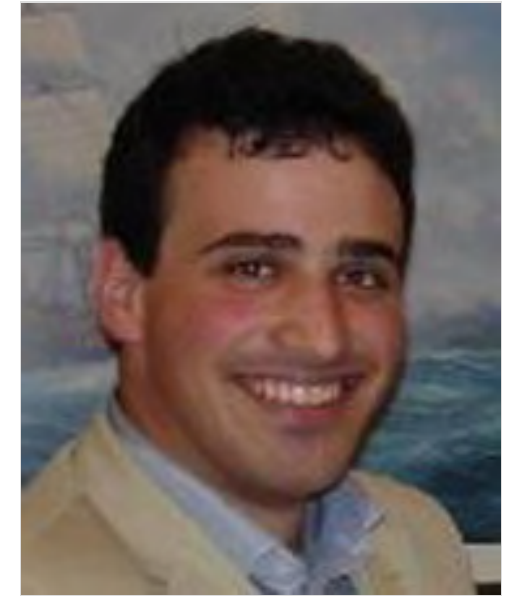

${ }^{1}$ Environmental Change Institute, OUCE, South Parks Road, Oxford, OX1 3QY UK 


\section{Abstract}

This paper explores the trends driving the growing demand for food imports to the Middle East North Africa (MENA) region through the lens of 'decoupling'. The analysis deploys a water-specific model of the general idea of resource decoupling to analyse the role and potential of food and virtual water trade in alleviating national and regional water limits. Decoupling theorises the breaking of the link between economic and population growth and need for water demand for domestic food production. A key means of reducing pressure on scarce water resources of a growing population is to increase the proportion of food sourced from abroad. This strategy has been strongly embraced politically in a number of MENA economies facing a combination of water and labour shortage. Food imports provide a politically silent mechanism to achieve national food security, and generate significant markets for food-exporting, water abundant, economies including those in the tropics. This paper combines FAO Food Balance data with Water Footprint data to reveal how virtual water flows interact with food import tonnages to enhance or retard national decoupling based on food trade. The analysis reveals that much MENA water is directed at crops adapted to the MENA climate. However, the analysis reveals significant potential for the import of large quantities of MENA water needs from more water abundant countries through supply of staple crops.

\section{Keywords}

Decoupling

Virtual water

Water footprint

Water security

Food trade

\section{Introduction}

This paper examines the role of water resource decoupling in enhancing or retarding blue water security in the Middle East North Africa (MENA) region. Decoupling refers to the breaking of the link between population and economic growth of an economy and its exploitation of its internal water 
resources. By substituting increasing domestic food production for increasing food imports, and with it the 'virtual water' content of those food imports (Allan 1998), the decoupling strategy has been variously embraced in a number of economies in the MENA region. These economies face a combination of water scarcity and limits posed by marginal lands. Food imports provide a politically silent mechanism to achieve national food security, and generate significant markets for food-exporting, water abundant, economies. Such food trade decoupling can be conceptualised as one mechanism for achieving a decoupling of national water resources from national economic and population growth. The analysis in this paper focuses on the food trade element of water resource decoupling and develops an emerging methodology of combining '50-year FAO Food-Balance Time Series' with Water Footprint Data to deliver a long-term simulation of internal and imported national water needs. The paper examines the idea of decoupling of water resources, and the specific methodologies deployed in this analysis. It then analyses the occurrence of food-trade based decoupling in the MENA region, exploring emergence of trends from the 1960s to late 1970s, and the water footprint impact of these decoupling trends in the 15 MENA countries with sufficient data. Finally, the paper summarises the largest agricultural water users in the MENA and the most water intensive crops, pointing to politically and biophysically practical means of using enhanced agricultural imports from tropical regions to reduce water scarcity and environmental risk in the MENA region.

\section{Decoupling: What is it? Why is it significant?}

Resource decoupling encompasses the idea of a weakened or broken relationships between natural resource use and economic and population growth. The idea of decoupling conceptualises how economies can growth at increasingly high rates without a commensurate increase in either stock- or flow-limited resources. The idea of resource decoupling emerged in the resource economics literature from the late 1980s (OECD 2001) with an increasing application to carbon emissions and energy needs of economies. The impact and power of decoupling is illustrated in the carbon intensity of economies, which declined from $1 \mathrm{kgCO}_{2} / \$$ in 1980 to $0.77 \mathrm{kgCO}_{2} / \$$ by 2006 (Jackson 2009). Similarly, Steinberger and Roberts (2010) observed a gradual increase in the carbon and energy efficiency of human development during the latter part of the 20th and into the 21st Century. Recent work by UNEP (2011, 2012) has attempted to draw a widely applicable theoretical 
framework of resource decoupling, incorporating the ideas of relative and absolute decoupling. The former involves less resource intensity per unit growth, but still involves an upward trend in resource use and economic growth. Absolute decoupling by contrast sees a real decline in resource use as economies growth.

\section{AQ2}

Jackson (2009) is highly critical of the perceived role of relative decoupling in achieving a sustainable global future, involving as it does the continued growth in total resources. He furthermore observes that the absolute decoupling required to deliver real reduction in global resource use is seldom, if ever observed. Where it is observed, the trends are likely to mask resource use embedded in international trade. While Jackson's argument on the need for absolute decoupling is strong when applied to the global impact of non-renewable resource use and carbon emissions, the argument is much weaker when applied to resources with distribution scarcity rather than global scarcity or limits. Water as a global resource for food production is generally recognised as being limited on local or national scales through availability and environmental resilience, with sufficient global resources for future needs (FAO 2007; Future Directions International 2014). Trade in food and other agricultural commodities, and with it 'virtual water' used to grow those imports, can act powerfully to reduce national and regional water limits and ameliorate global disparities in water distribution (Allan 2001, 2011). Acknowledging the importance of sub-global and national decoupling, and appreciating the role of trade and substitution of natural freshwater means that powerful and insightful trends in national fresh water resource decoupling can be identified, including absolute decoupling. More water abundant areas (endowed with either blue and/or green water) therefore offer a considerable opportunity to assist in the redistribution of global water resources through trade. Despite such food trades making a limited contribution to overall saving of water at a global scale (de Fraiture et al. 2004), their role in reducing pressure on water resources within water-scarce MENA national boundaries could be significant.

The potential for strategic use of food trade through its transfer of virtual water to alleviate limited water resources in water scarce countries is noted by many authors (including Chapagain and Hoekstra 2008; Roson and Sartori 2010 ). They argue clearly the potential for food trade to be used strategically to circumvent national water scarcity and pressure on unsustainable water 
resource expansion. These arguments are countered by other perspectives, notably those of Wichelns $(2010,2013)$ who is sceptical of the use of virtual water analyses as a criterion to guide food trade policies. Rather Wichelns (2013) argues that multiple economic and resource criteria (including price, reliability, capital and labour) not just water content will guide and influence policies on food trade, limitations also noted by de Fraiture et al. 2004(2004). While this complexity is not disputed here, this paper seeks to point to the potential offered by food trade to reduce the growth imperative on water resources in the MENA. Wichelns' argument on the multi-criteria nature of food trade are important, and invites a significant complexity into the whole issue of decoupling of water resources versus decoupling of other productive resources: however, to expand the analysis here is beyond the scope of this article.

Recent work acknowledging the role of trade and non-natural resource substitution has identified powerful water resource decoupling in Israel (Gilmont 2014) and Spain (Heemskerk 2014). Work by Gilmont (2014, 2015 ) identified three key mechanisms for water resource decoupling namely i) economic decoupling - shifts away from an agriculturally based economy due to economic diversification and other non-water related changes, ii) trade-based decoupling - use of food imports to increasingly meet growing population food needs, and iii) natural water decoupling - use of recycling and desalination technologies, allowing potential for return of natural water withdrawals to environmentally sustainable limits. The three stages are shown in Fig. 1. This paper focuses on the second stage of decoupling, as one that can have a large-scale impact on national water security for countries at all stages of development.

\section{Fig. 1}

Conceptual Model of decoupling (developed from Gilmont 2014) 


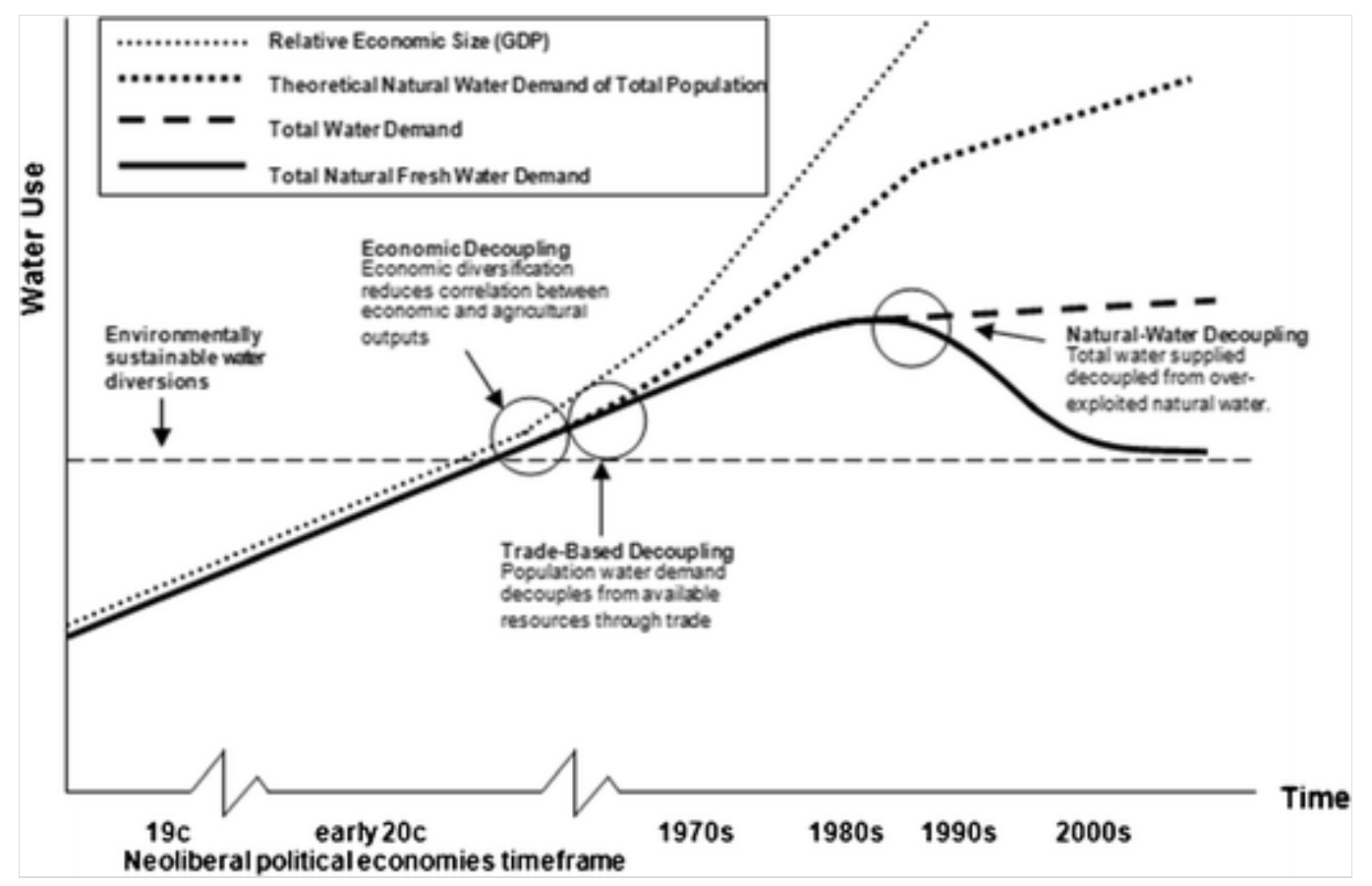

The significance of the modes of decoupling presented is that they encapsulate mechanisms by which economic and population growth put less strain on supply of natural water resources per head of population or unit of economic output. There is also potential for absolute reduction in national internal water resource use. As a result they mark changes in the nature of resource mobilisation, with important implications for policies and the political imperative of water growth.

Analysis through a decoupling lens is significant because it shows the political implications that decoupling has for food security. While Egypt currently imports around $40 \%$ of its wheat needs (FAO 2013), and has imported up to $25 \%$ of its total annual food tonnage needs during the $1980 \mathrm{~s}$ (ibid), a political rhetoric persists that Egypt is self-sufficient (Allan 1997). The evidence from Israel (Gilmont 2014) shows that the decision to increase food imports and reduce the nutritional imperative for mobilisation of natural water resources, was a strategic political choice. The contrast between Egypt's political denial of dependence, and Israel's strategic adoption of food imports shows that such processes can be a conscious or unconscious political decision. Identifying when, and by how much, a country may have embraced food-based decoupling illustrates the political challenges needed to further the use of this instrument as a means of moderating demands on scarce water resources.

The modes of decoupling in Fig. 1 do not include a key further element of decoupling, that of inter-annual economic growth rates from inter-annual 
changes in water availability. In extremis this coupling can significantly impact net economic growth trajectories, with Hall et al. (2014) drawing attention to Ethiopia (previously analysed by Grey and Sadoff 2007) where coupling between economic growth and drought is estimated to have reduced overall economic growth by $35 \%$ compared to scenarios of average rainfall. It is argued, however, based on (unpublished) analysis of 95 developing economies contributing to the analysis in Gilmont (2015) that sensitivity to inter-annual variability can remain even when overall economic/water trajectories have decoupled, with drought impacts being compensated on the return of normal rains. Variability decoupling can therefore be seen as, in some instances, being nested within the larger-scale decoupling trends, and is beyond the scope of the analysis in this paper. Future development of the analysis of water resource decoupling would usefully incorporate the variability element. Including the role of agricultural water efficiency would also be a useful extension of the analysis, although this has considerable measurement and quantification challenges.

Through analysis of the occurrence and extent of decoupling and trends achieved through changes in food production and food trade, potential avenues for enhanced national water security through trade can be highlighted.

\section{Decoupling Data and Water Footprinting}

Due to the poor measurement and accounting of water allocations in the vast majority of jurisdictions in the world and especially in the agricultural sector, long running time series of water use are few. By contrast, the FAO holds and publishes long-term time series of national food production, imports and exports. The food tonnage production data have been found by Gilmont (2014) to successfully mirror trends in recorded agricultural water use. Trends in domestic versus imported production have therefore been used to assess timing and extent of food-trade decoupling for over 80 developing economies from the 1960s to 2009 (Gilmont 2015). Such analysis allows the point to be identified at which food imports start to reduce the link between domestic food production (and therefore water use) and population food needs, and the extent of these changes.

While the use of food trade statistics demonstrates when an economy starts to embrace food imports to meet its growing food requirements, the data fails to capture the different virtual water content of each crop. This is significant 
from a water security perspective, in that food trade decoupling trends can be enhanced if water-intensive foods are prioritised for import, freeing up domestic production for less water intensive agriculture. This maximisation of the water impact of food trade can be termed 'water intelligent' food trade, i.e., the import of generally more water-intensive elements of food production. An absence of water intelligent food trade in water scarce economies can be identified in cases where water intensity of imports are at parity, or below intensity of internal production. Such cases do not mean these trends are not contributing to water resource decoupling, but that decoupling trends are not being enhanced as much as they could be. Water intelligent food trade therefore represents a mechanism by which the water-impact of food trade on decoupling trends is enhanced.

By combining FAO food balance tonnage data (FAO 2013) with water footprint data of Mekonnen and Hoekstra (2011), domestically produced and imported food tonnages can be weighted according to the relative water use in production. These calculations cannot be regarded as a fully accurate reconstruction of past agricultural water use due to methodological limitations discussed below. The approach does, however, allow a greater insight into the degree to which trade is used to proportionally reduce pressure on national water resources and, importantly for this paper, point to key crops and regions where trade policies could have a significant impact on national water scarcity.

Previous studies combining water footprint data and food production and trade tonnages have used time based snapshots, or averages over a short period of a few years, for example as carried out in Chapagain's and Hoekstra's (2008) analysis of food trade for 1997-2001. The analysis below provides a longer-term assessment of break points in food production trends across MENA economies weighted according to water footprint. The analysis therefore also allows, the relative changes in virtual water and food tonnage behaviours, as generated by changes in types of crops produced or traded (within the methodological limitations discussed below). Compared to a snapshot of food trade patterns, this analysis has additional political-economy implications for water and food security policy changes over time, be they witting or unwitting.

\section{Methodology}

\section{Food-trade decoupling}


The methodology uses FAO Food Balance Sheets (FAO 2013) to analyse changes in proportions of internal and imported food production from 1961 to 2009 for those countries with sufficient data. Total food production, imports and exports were calculated by summing appropriate FAO totals for each year. A lack of data on the composition of exports, namely proportion from domestic production and proportion from re-exported imported food meant that an accurate attribution of exports was not possible. For uniformity of calculation, all exports are assumed to derive from domestic production. The resultant food balance graphs therefore present food imports, domestic production and an export component subtracted from production. This assumption will not be correct for all countries but maintains both analytical uniformity and leaves total domestic production easily identifiable in graphs of production (exports+domestic). An example of the resultant food balance analysis for Jordan is shown in Fig. 2 and Israel in Fig. 3.

Fig. 2

Food Balance for Jordan, plotted with population, showing the increased role of food imports (i.e., decoupling) throughout the time series

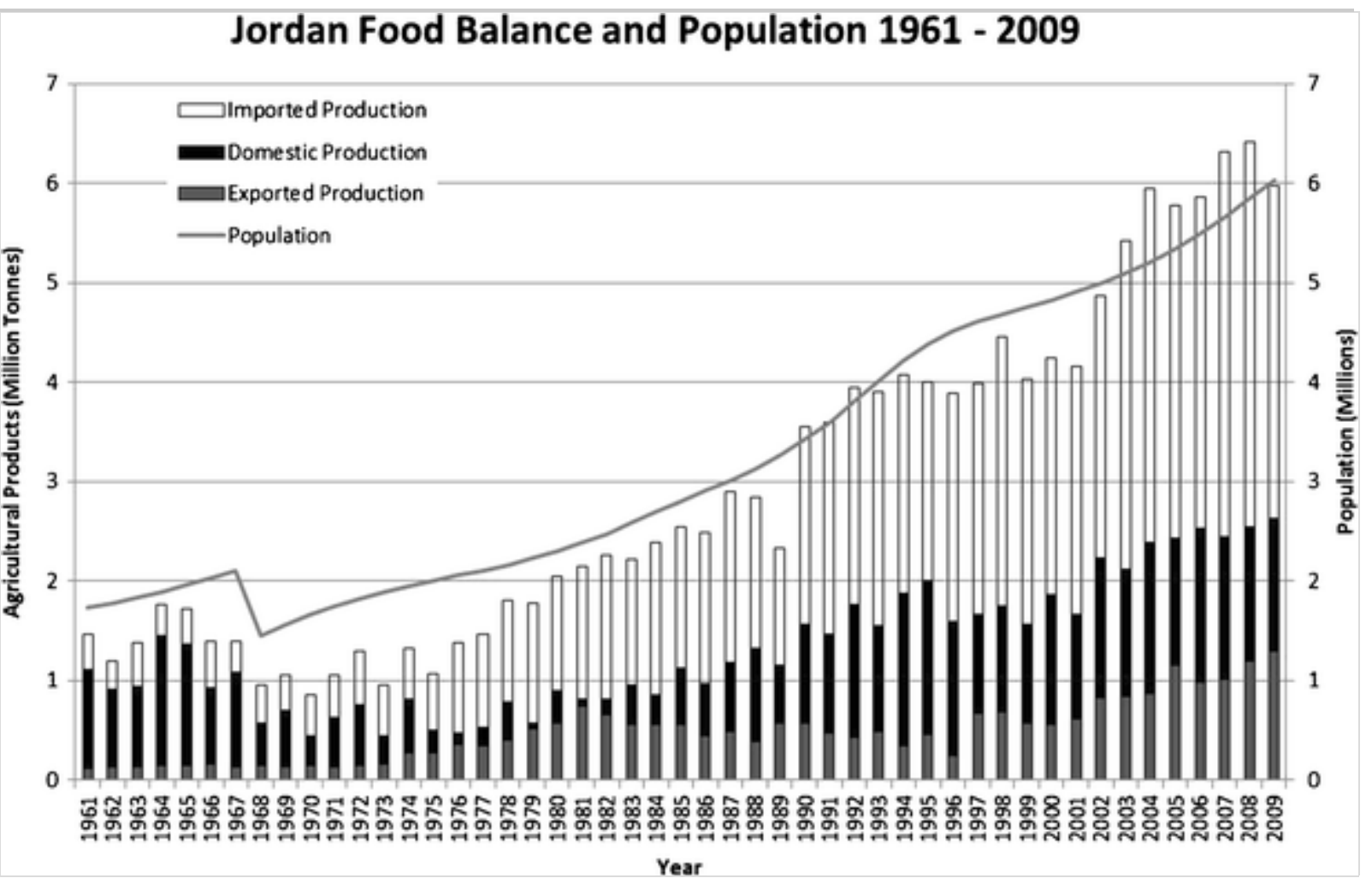


Fig. 3

Food Balance for Israel, plotted with population, showing the increased role of food imports in meeting population food needs from the mid-1970s, from Gilmont 2014

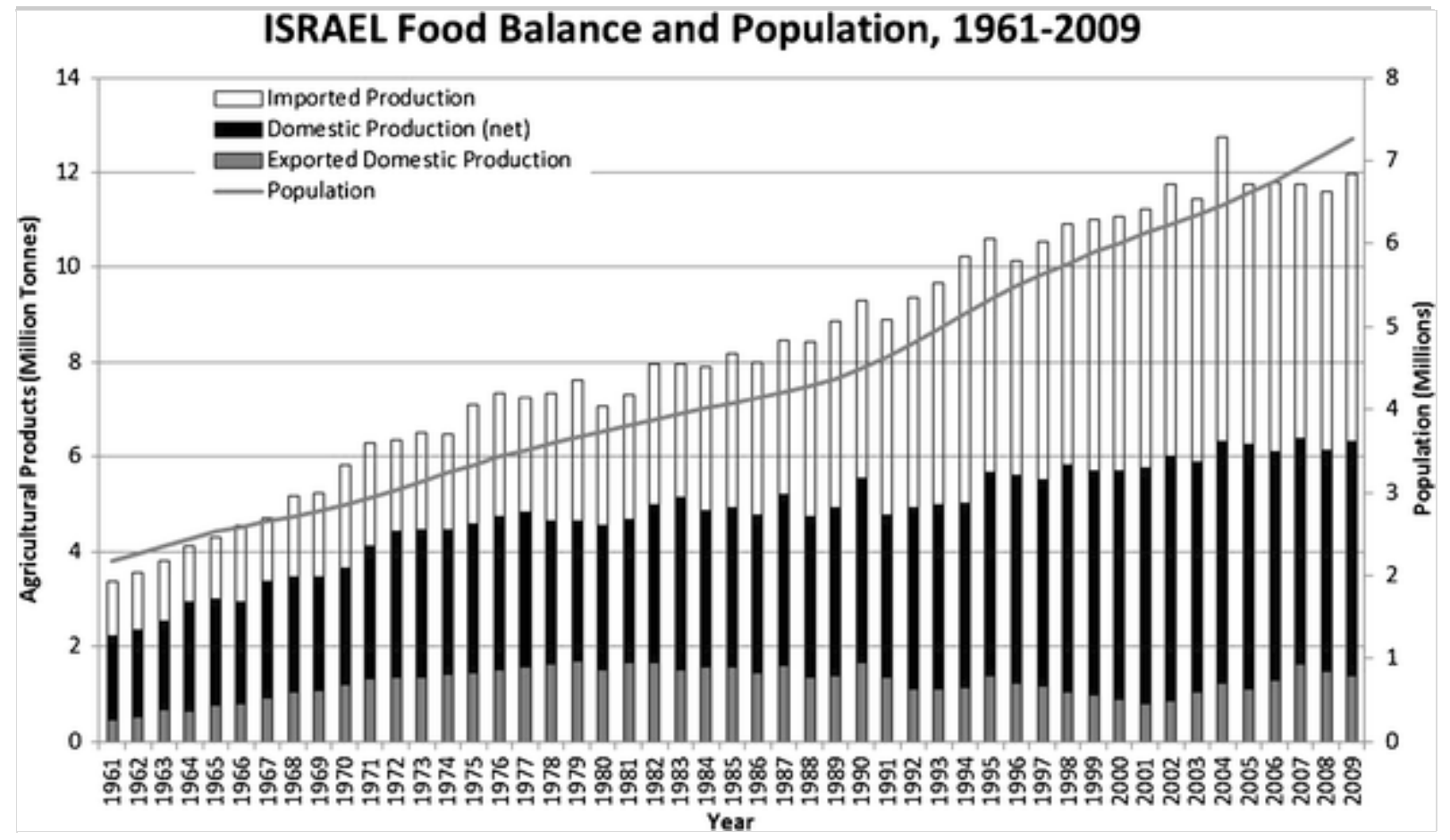

Where no historic coupling is seen to precede a decoupling trend, decoupling is assumed to have been initiated prior to the available data (normally 1961). For other countries where a steady-state percentage of Food-to-GDP and internal-to-imported food is observable, decoupling is regarded as occurring when the proportion of food needs met through imports increases by 1 standard deviation of a previous mean and remains above this deviation for periods of 5 or more years. As an example, the statistical determination of decoupling for Israel is shown in Fig. 4. Israel also exhibits recoupling from the 1990s at $48 \%$ and the net impact of decoupling can therefore be said to be $15 \%$. Where decoupling trends are ongoing, any calculation of net decoupling in this paper is the difference between pre-decoupling imports and the last available year (normally 2009).

Fig. 4

Decoupling trend as statistically determined for Israel 


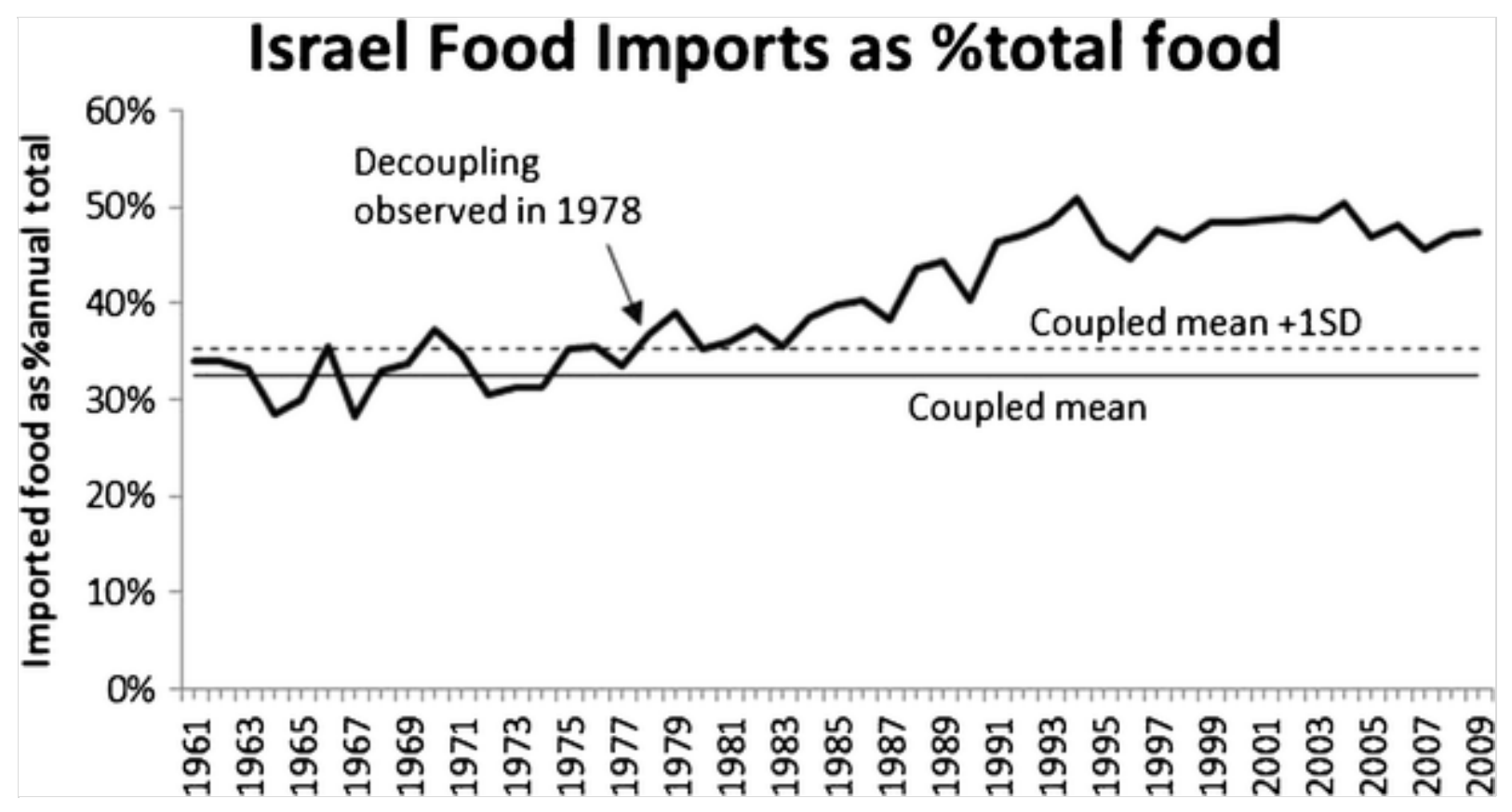

A further investigation of decoupling trends is possible by applying the water footprint data of Mekonnen and Hoekstra (2011) to the FAO food balance data. This indicates if the tonnage-based decoupling trends are further enhanced or retarded on the basis of the virtual water contained within national and imported agricultural production. The calculations show the relative water intensity of national and imported production. In water-scarce economies, or those with significant semi-arid water-scarce land areas, importing the most water-intensive elements of a population's food needs will act to reduce pressure on national water resources and the freshwater environment. Imports should also reduce the food-security impetus for inappropriate agricultural expansion into semi-arid areas. Furthermore the calculations allow an assessment of the most water intensive crops and the largest total crop water users. These analyses provide an insight into the potential for other more water-abundant areas of the world to substitute food supply through trade.

The water footprint data from Mekonnen and Hoekstra (2011) contains estimated blue, green and grey water for each main agricultural commodity for each country. Blue water represents water abstracted from the natural environment and applied by human activity, namely crop irrigation. Green water is the water held within the soil profile, previously falling as rain or dew that is used by plants and animals to grow. Grey water represents the freshwater volume required to dilute pollutants (for example agricultural runoff) to agreed standards. Due to the water quality role of grey water, the fact that it remains available for environmental volumetric flows, and the 
difficulty in accounting for it within national water accounts, this component is not considered.

Water Footprint Data was available for every major agricultural food commodity reported by the FAO except Honey. The water footprint data does not include non-food alcohol, while the FAO Food Balance data does not include non-food agricultural activity, including fibre and horticulture. This omission will impact results for countries with large elements of agriculture in these categories. It is anticipated that the resultant error for MENA economies will be limited compared to areas of Southern Africa and the Americas which have significant biofuel and horticultural industries.

Efforts were made in the analysis to reduce 'double counting' water in both crops and animal products. The Water Footprint data for animal products includes the water footprint of vegetable matter used as feed. FAO Food Balance datasheets include a component for crop tonnages converted to feed. The water footprint of these tonnages were therefore subtracted from the animal water footprint for the domestic and export markets proportional to animal tonnages to the two markets. Due to a lack of country-specific data on feed tonnages per meat tonnage, this calculation could only be carried out for total water footprints and not individual products. This means that water intensities of animal products discussed later includes the footprint of feed supplied to the animals.

The water footprint data is benchmarked to the period 1996-2005. Within this benchmarking, Mekonnen and Hoekstra apply a weighting for crop imports based on the known national sources of agricultural imports during the benchmark period (Mekonnen and Hoekstra 2011). This presents a key limitation to the long-term use of the benchmark data. Where a particular crop is both produced domestically and imported, the benchmark will not properly reflect either source, although it will reflect total water use of the combination. If an imported crop uses less water than its internal equivalent, the water footprint as applied to internal production will be lower than the likely true value. Similarly, as internal and imported production percentages change back in time, or the source of imports change, the representativeness of benchmarked data will be reduced.

The benchmarking of water footprints to the 1996-2005 period means that historic water use calculations prior to the benchmark period will likely under-estimate true water use. This is due to changes in irrigation efficiency 
and other agricultural practices, including crop varieties and soil conditioning, as well as possible changes in country of origin of food imports over time. The impact of this deviation is shown in Figs. 5 and 6 for Blue Water use in Jordan and Israel. These two countries were used in the verification of the footprinting of food balance data used in this paper, due to the length of their agricultural water time series and, in the case of Israel, generally agreed reliability of agricultural water data (Gilmont and Allan 2014). While water footprinting of food balance sheets therefore has some limitations, the methodology isolates and exposes changes in water use behaviours due to shifts in crop types and trade. In this respect, the use of a static benchmark has considerable analytical power.

\section{Fig. 5}

Comparison of modelled Blue Water use in agriculture and official statistics for Jordan, demonstrating general convergence for the post-2000 period. Data: Taha 2006 and MWI 2012

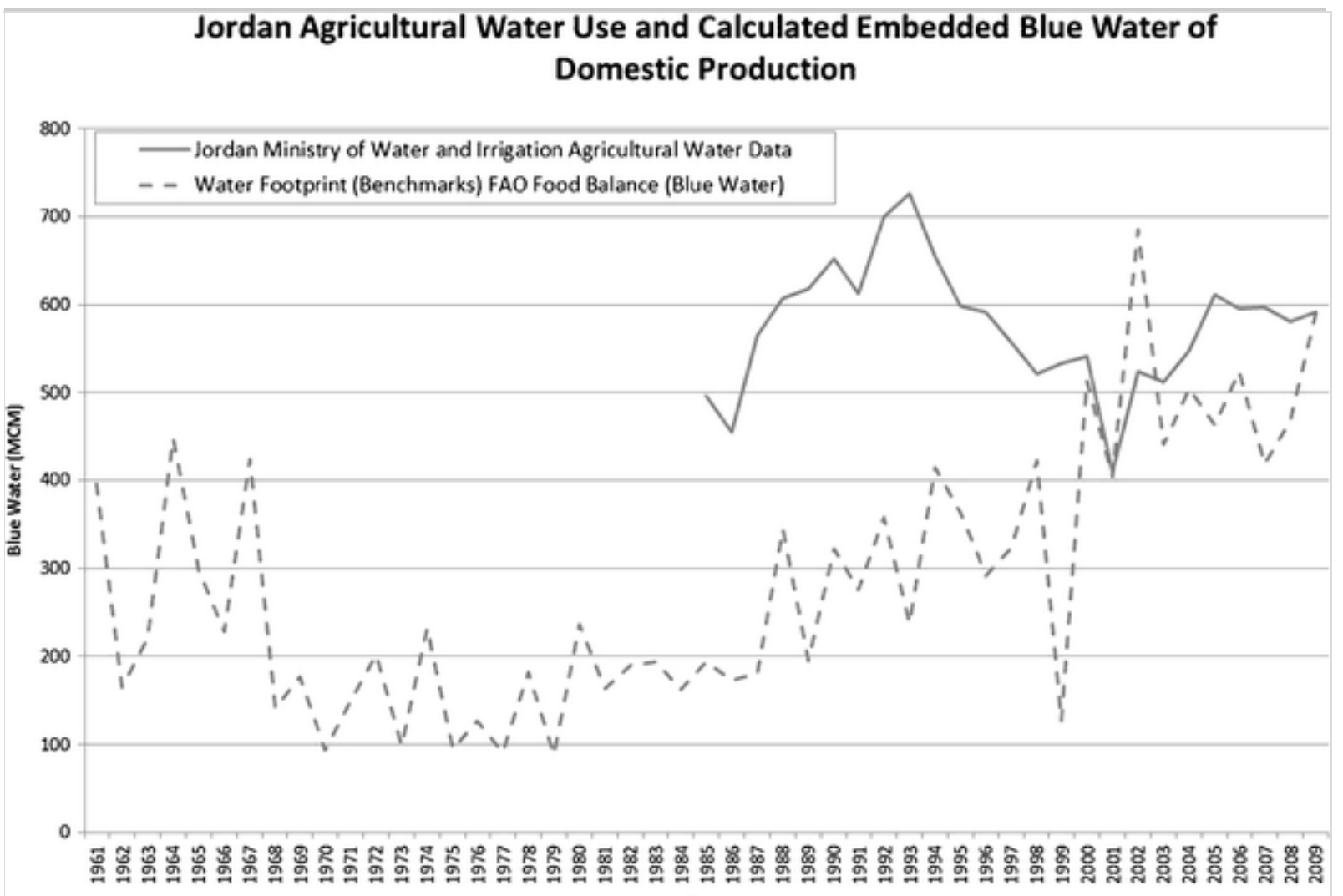




\section{Fig. 6}

Comparison of modelled Blue Water use in agriculture and official statistics for Israel, demonstrating effective and elements of inter-annual variation for the post-2000 period. Data: Israel Central Bureau of Statistics (2005, 2008, 2013) and State of Israel 2002

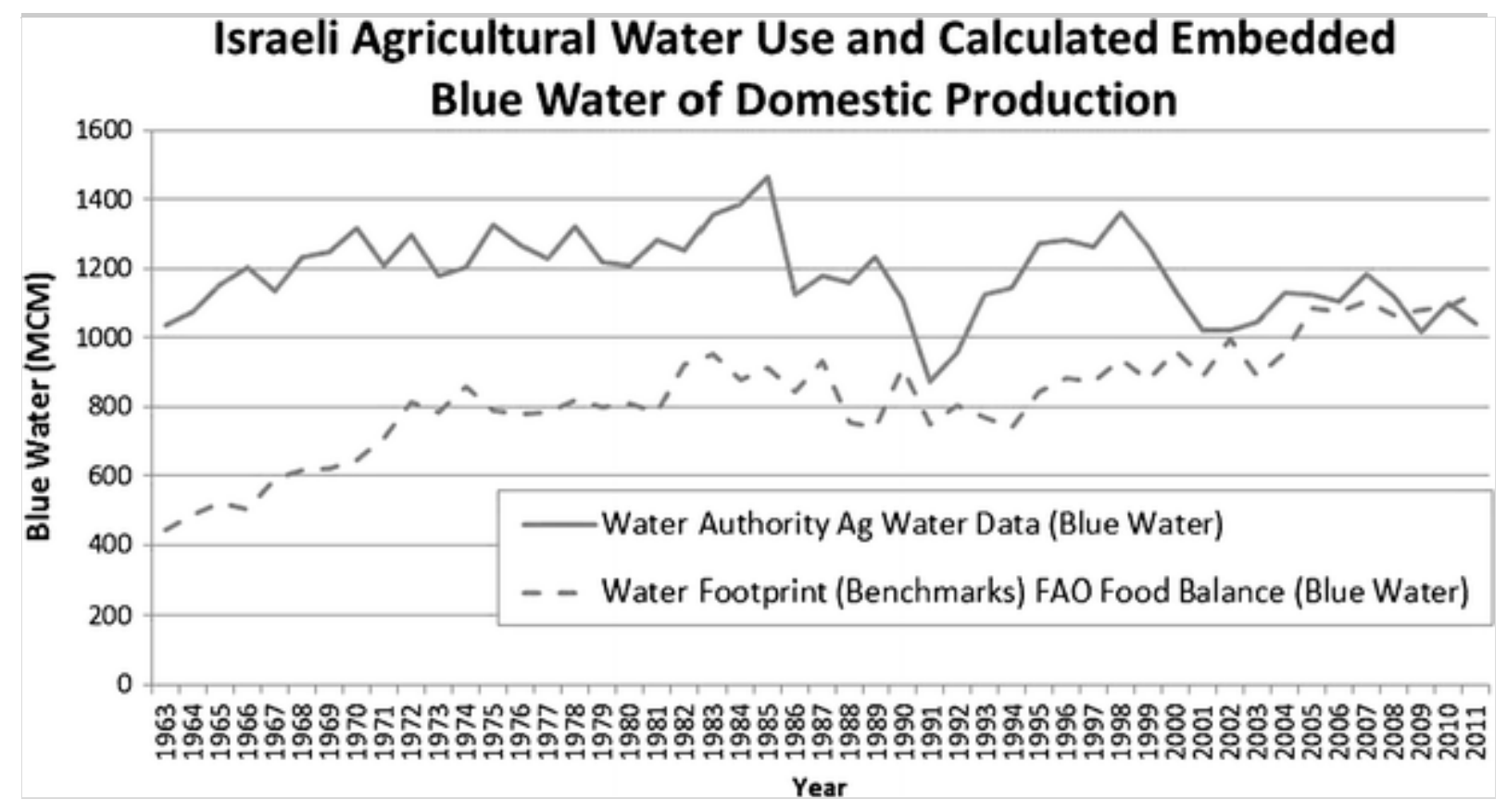

Despite historical divergence, the modelled agricultural blue water use has a relatively strong agreement in both Jordan and Israel for the period around 2000 (centre of the benchmark period) onwards. Despite the divergence of modelled and actual agricultural water use, the historical divergence should hold for both internal and external water. Therefore changes in proportions of agricultural water from internal and external sources will be captured even if the absolute numbers are incorrect.

Further testing has been carried out on the green water element of the calculations. While there is no way to effectively measure green water use across a national agricultural sector, green water is by its nature dependent almost entirely on rainfall. It would therefore be expected that green water contained within agricultural commodities would decline and increase relative to fluctuations in rainfall (assuming constant cropping areas). Figure 7 demonstrates a correlation between modelled interannual change in green water footprint for Israel and interannual variation rainfall as measured in Nablus (Palestinian Territories), the long Nablus time series being an effective proxy for Israel as a whole (Gilmont 2014). The trend evident in Fig. 7 proves that the combined Water Footprint data and FAO Food Balance Sheet 
data for crops does appear to have reasonable sensitivity to interannual variations in green water and with it confirms the ability of the combined FAO and Water Footprint data to capture the water-content of agriculture more generally.

\section{Fig. 7}

Interannual changes in green water footprint and rainfall for Israel



Figures 5, 6 and 7 demonstrate that though the water footprinting methodology has some inherent weaknesses, inter-annual variations and changes over time are captured and appear relatively robust, and converge to representative volumes of agricultural water. One final caveat is the methodological dependence on the quality of the FAO Food Balance data, and the diligence and accounting of the national statistical agencies who compile it. The verification examples of Israel and Jordan represent some of the higher capacity MENA economies with significant industrialised agricultural sectors. For lower capacity cases, or those with a high proportion of subsistence or non-commercial agriculture, significant proportions of annual tonnage will not be reported by the FAO (FAO 2001; Jacobs and Sumner 2002).

The following analysis will focus on decoupling trends in the thirteen MENA countries for which sufficient data exists. It will be centred on the analysis of Blue Water. The significance of Green Water in agricultural production should not be under-estimated, comprising as it does around $84 \%$ of total global crop water requirement (Fadder et al. 2011). Despite its importance in crop production, green water has little productive application in other sectors, and cannot be directly managed. Water-related environmental impact of agriculture, and agricultural impacts on water availability in the natural environment are by contrast closely tied to Blue Water. Abstraction of water 
for irrigation has led to the decline of aquatic environments around the world. In recent years, the rapid growth of higher value uses for blue water, namely industrial and urban demand is placing increasing pressure on agricultural water allocations within the MENA (Greco 2014).

\section{Analysis of Results}

ThirteenFourteen economies were identified for which sufficient data existed to analyse decoupling and water footprints. They are shown in Table 1, which includes the dates of their commencement of decoupling and the net change in dependence on food tonnage imports due to the decoupling process, and finally the end date of a decoupling (if not an ongoing trend) which would mark a recoupling at a new level of import dependency. 


\section{Table 1}

Year of decoupling and recoupling, (or latest in-trend year in parenthesis), with the net change in $\%$ food tonnage imports achieved due to decoupling

\begin{tabular}{|c|c|c|c|c|c|}
\hline $\begin{array}{l}\text { MENA } \\
\text { Country }\end{array}$ & $\begin{array}{c}\text { Decoupling } \\
\text { Year }\end{array}$ & $\begin{array}{l}\text { Pre-Decoupling } \\
\text { food imports } \\
\text { (tonnes) }\end{array}$ & Recoupling & $\begin{array}{c}\text { Post } \\
\text { Decoupling } \\
\text { food } \\
\text { imports } \\
\text { (tonnes) }\end{array}$ & $\begin{array}{c}\text { Net } \\
\text { Change }\end{array}$ \\
\hline Algeria & 1972 & $17.14 \%$ & 1978 & $49.70 \%$ & $32.56 \%$ \\
\hline Egypt & 1974 & $9.80 \%$ & 1984 & $25.00 \%$ & $15.20 \%$ \\
\hline Iran & 1974 & $5.40 \%$ & 1984 & $18.06 \%$ & $12.66 \%$ \\
\hline Israel & 1978 & $32.53 \%$ & 1991 & $47.71 \%$ & $15.18 \%$ \\
\hline Jordan & $<1961$ & $24.28 \%$ & 1976 & $58.65 \%$ & $34.37 \%$ \\
\hline Kuwait & $<1961$ & $90.40 \%$ & $(2009)$ & $83.78 \%$ & $-6.62 \%$ \\
\hline Lebanon & $<1961$ & $35.19 \%$ & 1987 & $47.45 \%$ & $12.26 \%$ \\
\hline Yemen & 1977 & $22.90 \%$ & $(2009)$ & $60.87 \%$ & $37.97 \%$ \\
\hline UAE & $<1961$ & $27.59 \%$ & $(2009)$ & $87.88 \%$ & $60.29 \%$ \\
\hline Libya & $<1961$ & $35.00 \%$ & 1970 & $58.75 \%$ & $23.75 \%$ \\
\hline Morocco & 1977 & $12.42 \%$ & $(2009)$ & $21.27 \%$ & $8.85 \%$ \\
\hline Saudi & 1976 & $41.23 \%$ & (2009) & $67.91 \%$ & $26.68 \%$ \\
\hline Syria & 2002 & $14.14 \%$ & (2009) & $31.79 \%$ & $17.65 \%$ \\
\hline Tunisia & 1978 & $16.51 \%$ & $(2009)$ & $25.30 \%$ & $8.79 \%$ \\
\hline
\end{tabular}

The following analysis will examine these food tonnage trends for each country, along with the trends in blue water footprint to assess whether decoupling trends are enhanced in relative terms through their water content, and therefore whether 'water intelligent' food trade is being adopted. The analysis enables an assessment of those countries where significant gains in water security could be achieved through future water-intelligent food trade. It will also enable an assessment of the largest water users in agriculture in the MENA region and the most water-intensive crops as of 2009. These data therefore invite assessment as to how agricultural products from tropical regions could enhance water security in the MENA. While focusing on blue water, attention is drawn to the ability of international trade to substitute blue 
water in one location with green water from other more water-abundant locations. Such substitution could result in a degree of global net absolute blue water decoupling. All calculated water data are given in Million Cubic Meters (MCM).

\section{Algeria}

Prior to decoupling in 1972, Algeria imported $17 \%$ of its food needs, which contained an average of $5.5 \%$ of its blue water needs. While Algeria executed a rapid and considerable decoupling to 1978 to an average of $49.7 \%$, the proportion of blue water continued to be well below the levels of imported food, averaging $31.13 \%$ (Fig. 8). For both water content and food trade, there is considerable inter-annual variation. The picture both pre and post decoupling shows an absence of water-intelligent food trade.

Fig. 8 Algeria: Percentage Food Tonnage Imports and Blue Water Imports

\section{AQ3}

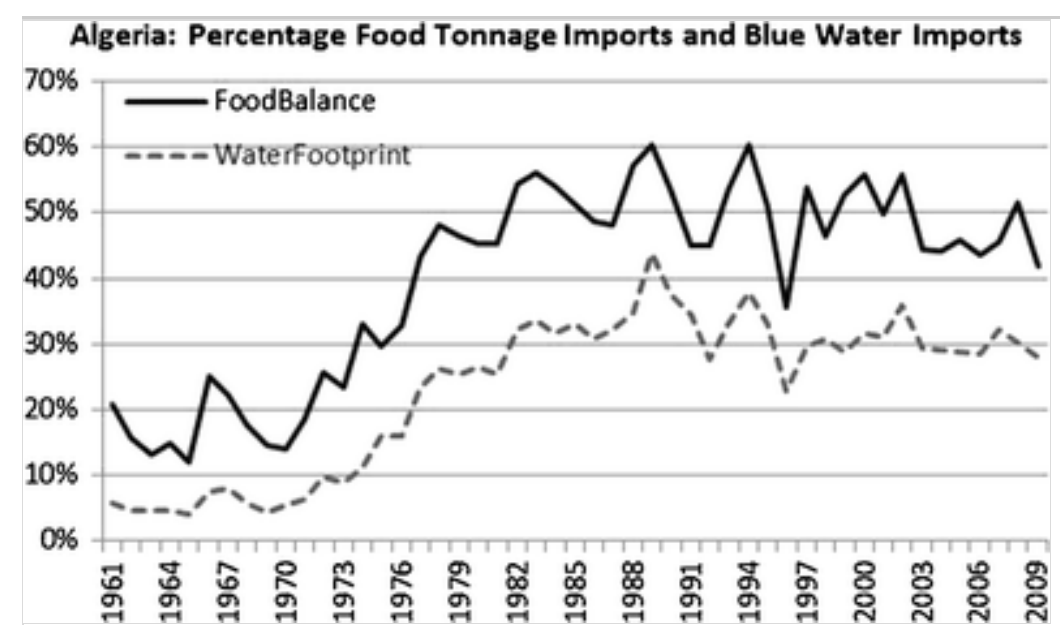

A comparison of internal and external water intensity for Algeria during 1961-2009 (Fig. 9) demonstrates that the blue-water intensity of food imports has remained significantly below that of internal production. There is however a steady decline in internal water intensity up to the early 1990 s from $850 \mathrm{~m}^{3} / \mathrm{t}$ to an average of $282 \mathrm{~m}^{3} / \mathrm{t}$ between 2000 and 2009. Over the same period however external water intensity reduced by formfrom 196 to $134 \mathrm{~m}^{3} / \mathrm{t}$. There may be significant opportunity for import of water-intensive crops to further reduce water intensity (and therefore blue-water requirements) of internal agricultural production in Algeria.

Fig. 9 Algeria Blue Water Intensity 


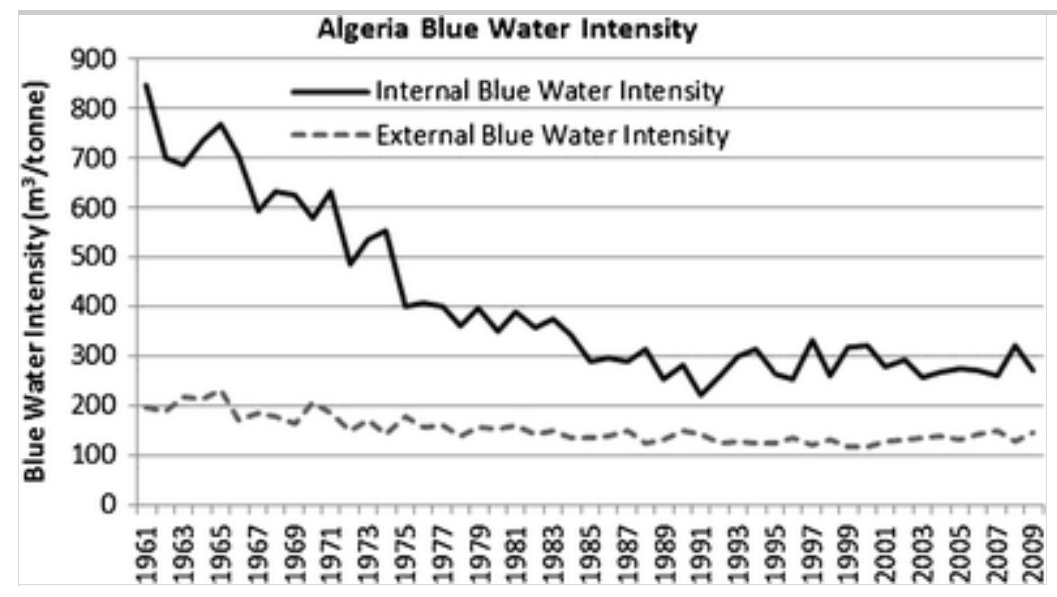

The most water-intensive agricultural products in Algeria, according to FAO groupings, are 'Meat, Other' at $6412 \mathrm{~m}^{3} / \mathrm{t}\left(\right.$ global average $637 \mathrm{~m}^{3} / \mathrm{t}$ ), with 'Olive Oil' the second largest (and largest non-animal product) at $4372 \mathrm{~m}^{3} / \mathrm{t}$ (global average $2388 \mathrm{~m}^{3} / \mathrm{t}$ ). The largest water users in Algeria are 'Dates', using 1372MCM (intensity $2284 \mathrm{~m}^{3} / \mathrm{t}$ ) in 2009, followed by 'Grapes' using $565 \mathrm{MCM}$ (intensity $1137 \mathrm{~m}^{3} / \mathrm{t}$ ).

\section{Egypt}

Prior to decoupling Egypt imported $9.8 \%$ of its annual tonnage food needs, containing $13 \%$ of its annual blue water needs. Even before decoupling, Egypt was adopting water-intelligent trade. In 1984, Egypt was importing around $25 \%$ of its annual food needs, containing $37 \%$ of its water needs. Its decoupling trend then regressed and by 2009 Egypt was importing $12.6 \%$ of its food needs and $17.75 \%$ of its blue water (Fig. 10).

Fig. 10 Egypt: Percentage Food tonnage Imports and Blue Water Imports

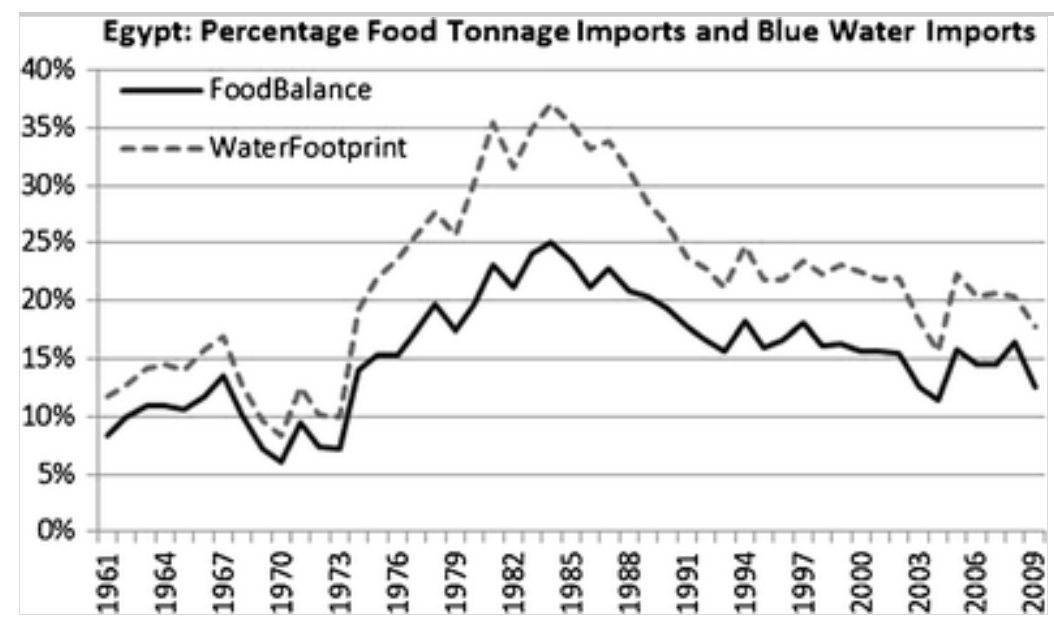




\section{AQ4}

Analysis of Blue Water Intensity (Fig. 11) shows a slight decline in both internal and external water intensities over the period to 2009 from around 500 to 450 and 700 to $650 \mathrm{~m}^{3} / \mathrm{t}$ respectively. By 2009, the largest most waterintensive agricultural products were 'Olive Oil' at $7501 \mathrm{~m}^{3} / \mathrm{t}$ (global average $2388 \mathrm{~m}^{3} / \mathrm{t}$ ) and 'Spices, Other' at $7091 \mathrm{~m}^{3} / \mathrm{t}$ (global average $\left.715 \mathrm{~m}^{3} / \mathrm{t}\right)$. The largest users of agricultural water are 'Rice (Milled Equivalent)', consuming $5802 \mathrm{MCM}$ of water in 2009 (intensity $1576 \mathrm{~m}^{3} / \mathrm{t}$ ), and 'Maize' at 5028MCM $\left(713 \mathrm{~m}^{3} / \mathrm{t}\right)$.

Fig. 11 Egypt Blue Water Intensity

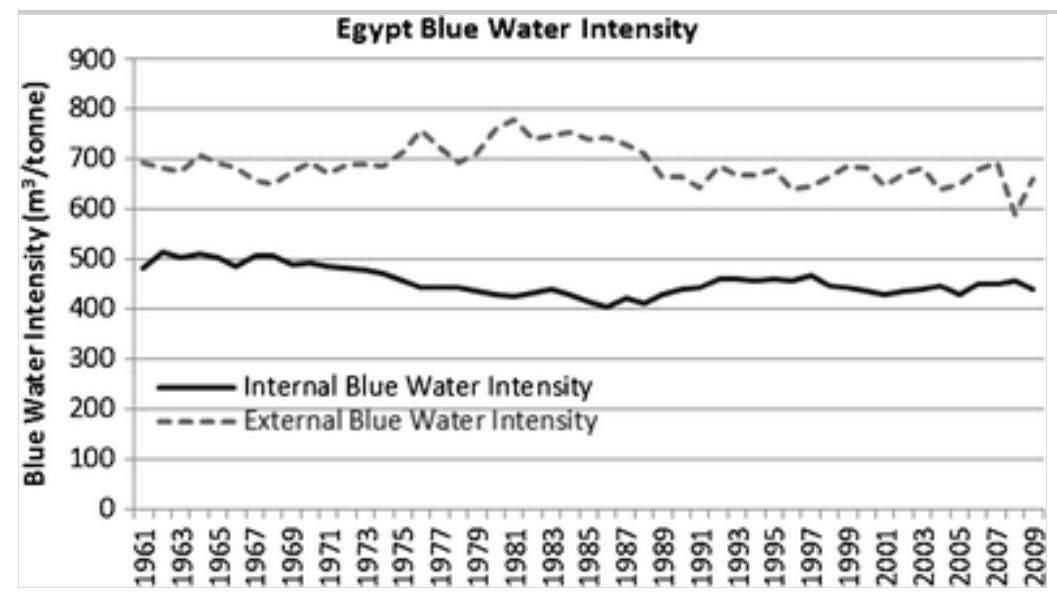

\section{Iran}

Iran imported $5.4 \%$ of its food needs and $6.7 \%$ of its blue water needs. Prior to decoupling in 1974, very little water-intelligent food trade was noted, with water footprint of imports noticeably greater than food tonnage imports from 1971. Since 1984 however, Iran has been importing on average $13.2 \%$ of its annual food needs comprising $18.12 \%$ of its blue water needs with considerable inter-annual variation (Fig. 12). It has embraced moderate waterintelligent trends, with a relative increase in intensity of imports relative to internal production.

Fig. 12 Iran: Percentage Food Tonnage Imports and Blue Water Imports 


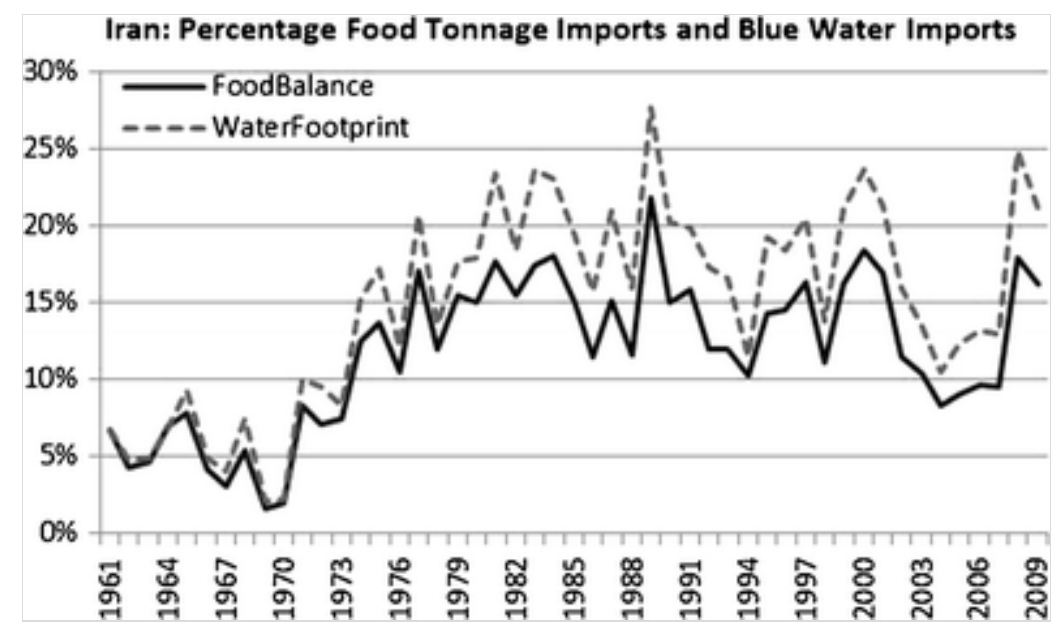

An analysis of Iranian blue water intensities shows that the water-intelligent food trade has been achieved through a gradual decline in internal water intensity from $624 \mathrm{~m}^{3} / \mathrm{t}$ in 1961 to $467 \mathrm{~m}^{3} / \mathrm{t}$ in 2009 . At the same time, the blue water intensity of imports has averaged $683 \mathrm{~m}^{3} / \mathrm{t}$ (Fig. 13). As of 2009 most water intensive domestic products are 'Olive Oil' at 14,092 $\mathrm{m}^{3} / \mathrm{t}$ (global average $2388 \mathrm{~m}^{3} / \mathrm{t}$ ) and 'Pimento' at $7438 \mathrm{~m}^{3} / \mathrm{t}$ (global average $1125 \mathrm{~m}^{3} / \mathrm{t}$ ). The largest water users are 'Wheat' (9938MCM, intensity $737 \mathrm{~m}^{3} / \mathrm{t}$ ) and 'Fruits, Other' (3912MCM, intensity $976 \mathrm{~m}^{3} / \mathrm{t}$ ).

Fig. 13 Iran Blue Water Intensity

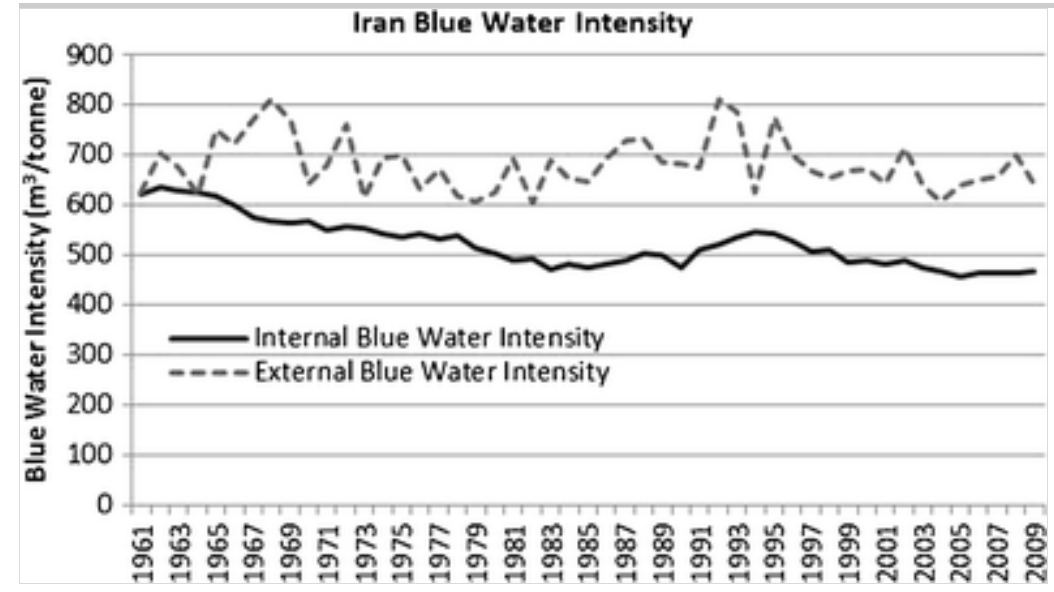

\section{Israel}

Prior to its decoupling in 1978, Israel was not only not exhibiting waterintelligent food trade, it was actually importing crops with lower water intensities than its domestic production;, importing $32.5 \%$ of its food needs comprising $26.1 \%$ of its blue water requirements. During the decoupling process the disparity tightened such that after 1991, Israel imports $47.7 \%$ of 
its annual food needs comprising $46.9 \%$ of its annual food needs (Fig. 14).

Fig. 14 Israel: Percentage Food Tonnage Imports and Blue Water Imports

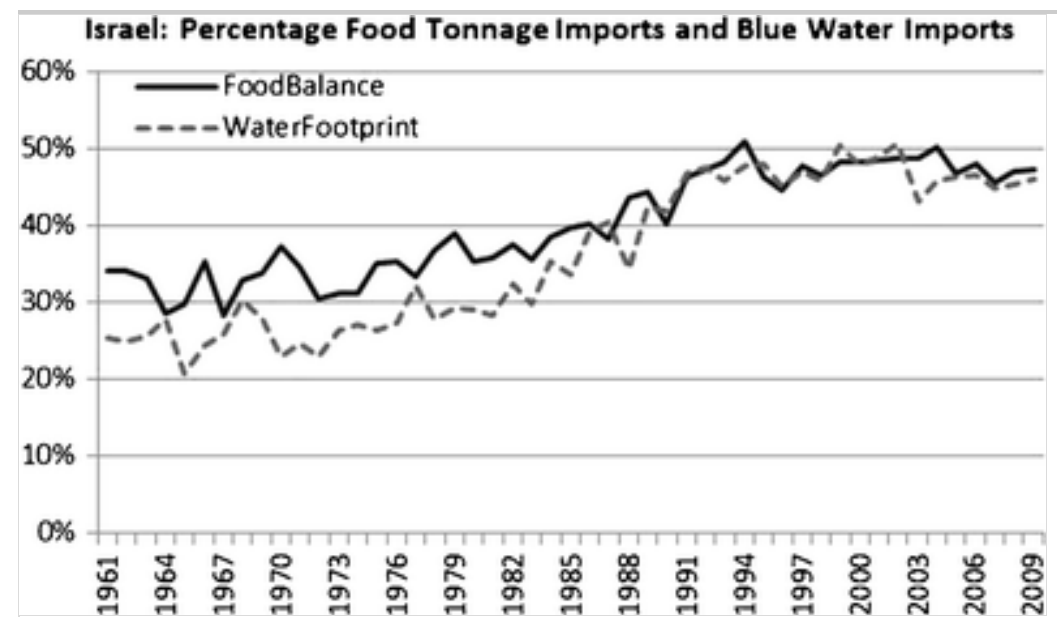

Figure 15 demonstrates the simultaneous decline in internal and rise in external blue water intensities that have facilitated the convergence of food and blue water import percentages. In 1961 internal blue water intensity was $201 \mathrm{~m}^{3} / \mathrm{t}$ while external intensity was $133 \mathrm{~m}^{3} / \mathrm{t}$. In 1987, internal intensity dropped to $142 \mathrm{~m}^{3} / \mathrm{t}$ while external intensity was at $154 \mathrm{~m}^{3} / \mathrm{t}$, with approximate parity maintained subsequently. It should be noted that a considerable proportion of agricultural blue water is recycled urban effluent due to Israel embracing natural water decoupling (discussed in Gilmont 2014 ). The real intensity of fresh blue water is therefore considerably lower than the import intensities.

Fig. 15 Israel Blue Water Intensity

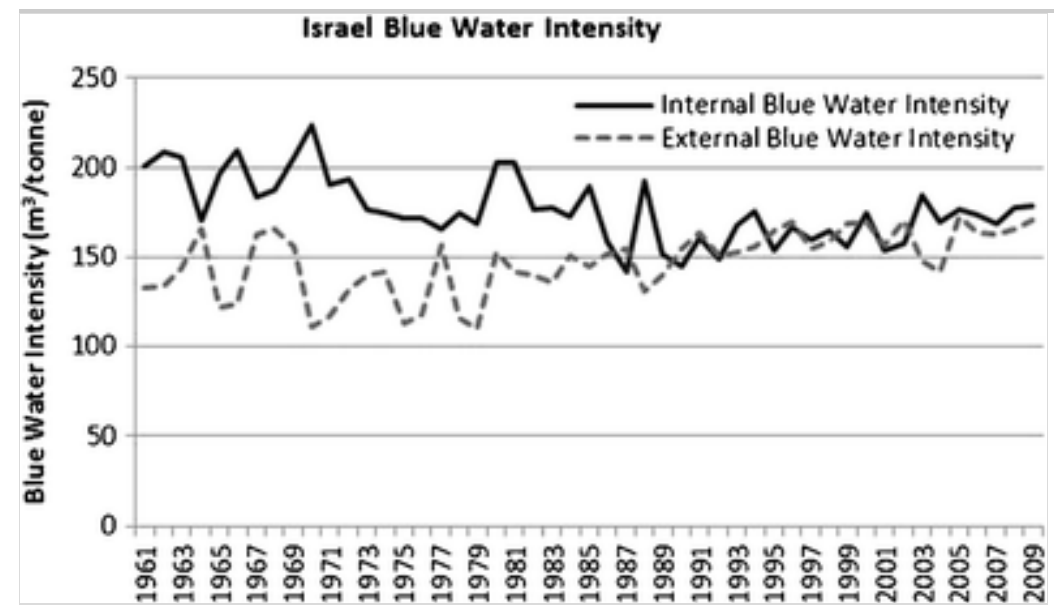


As of 2009, Israel's most water intensive crops are 'Oilcrops Oil, Other' and 'Oilcrops. Other' at 7817 and $4219 \mathrm{~m}^{3} / \mathrm{t}$ (global averages 708 and $389 \mathrm{~m}^{3} / \mathrm{t}$ respectively), with Olive Oil at $3680 \mathrm{~m}^{3} / \mathrm{t}$ (global average $2388 \mathrm{~m}^{3} / \mathrm{t}$ ). The largest crop users of water in 2009 were 'Fruits, Other' requiring 233MCM (intensity $650 \mathrm{~m}^{3} / \mathrm{t}$ ) and 'Vegetables, Other' requiring 170MCM (intensity $\left.137 \mathrm{~m}^{3} / \mathrm{t}\right)$.

\section{Jordan}

As discussed above, Jordan's decoupling predates the 1961 commencement of Food Balance data. Between 1961 and an observed recoupling around 1976 Jordan's food and blue water imports increased from 24.3 and $23.7 \%$, respectively, to 58.2 and $70.1 \%$ respectively (Fig. 16), demonstrating a clear water-intelligent food trade trend of increased water intensity of imports relative to internal production. However, as Figs. 16 and 17 illustrates, intensities of both internal and external production have declined due to changes in crop type (in addition to efficiencies and other factors not captured in this methodology).

Fig. 16 Jordan: Percentage Food Tonnage Imports and Blue Water Imports

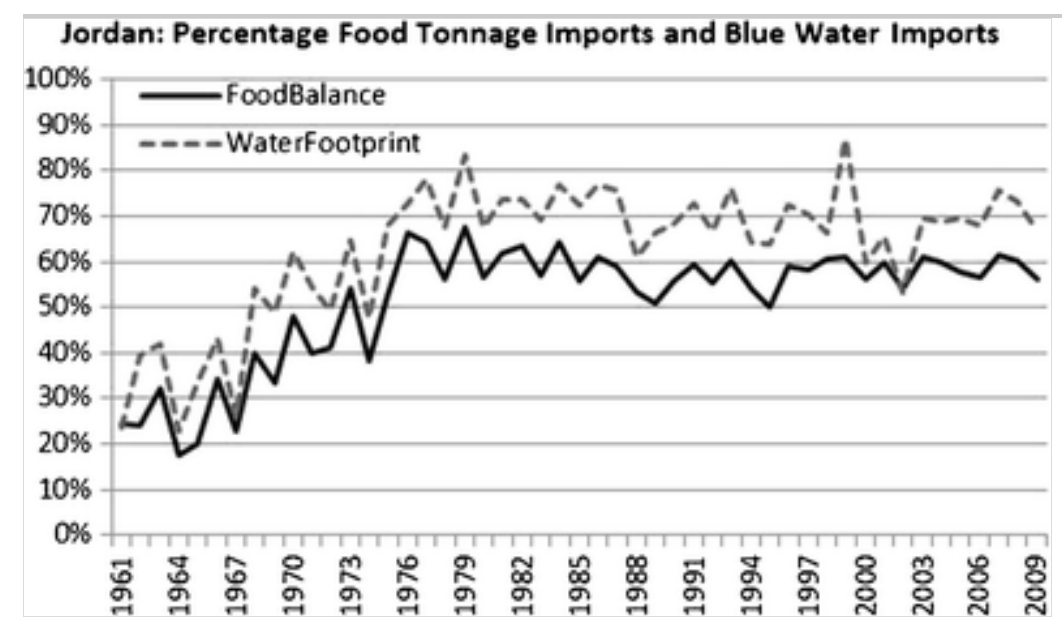

Fig. 17 Jordan Blue Water Intensity 


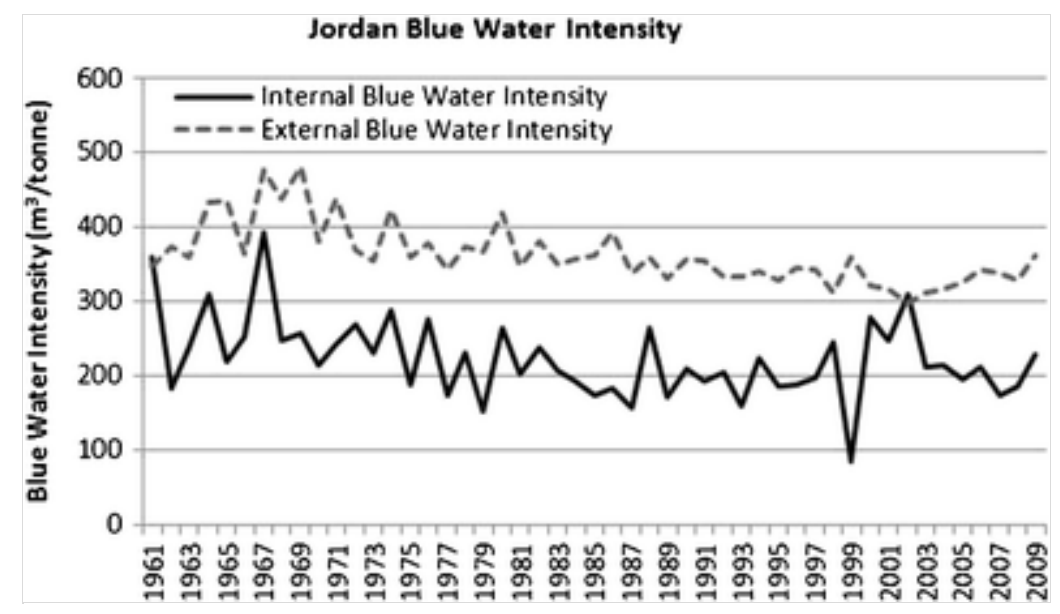

AQ5

As Fig. 17 demonstrates, Jordan's internal blue water intensity has fluctuated from 1961 to 2009 , with a downward trend from $360 \mathrm{~m}^{3} / \mathrm{t}$ in 1961 to $228 \mathrm{~m}^{3} / \mathrm{t}$ in 2009. External water intensity has shown rising and falling trends but the net change between $1961\left(348 \mathrm{~m}^{3} / \mathrm{t}\right)$ and $2009\left(361 \mathrm{~m}^{3} / \mathrm{t}\right)$ is minimal. A water intelligent trade therefore appears to have been adopted through changes in crop type in domestic agriculture alone, that has reduced the water intensity of production, rather than active substitution of exports for more water intensive crops.

As of 2009 'Olive Oil' at $5139 \mathrm{~m}^{3} / \mathrm{t}$ (global average $\left.2388 \mathrm{~m}^{3} / \mathrm{t}\right)$ and 'Sesameseed Oil' at $2896 \mathrm{~m}^{3} / \mathrm{t}$, (global average $1183 \mathrm{~m}^{3} / \mathrm{t}$ ) represent the most water intensive Jordanian crops. 'Olives' and 'Poultry Meat' are the largest users of water in Jordanian agriculture, requiring 150MCM (intensity $1063 \mathrm{~m}^{3} / \mathrm{t}$ ) and 114MCM (intensity $744 \mathrm{~m}^{3} / \mathrm{t}$ ) of water respectively in 2009 .

\section{Kuwait}

The small gulf state has no observable decoupling, but historically has decoupled, importing a large majority of its food needs. Between 1961 and 2009 it experienced a small and ongoing decline in food imports from $90.4 \%$ in 1961 to $83.8 \%$ in 2009. Percentage of blue water imports declined from $93 \%$ in 1961 to $88.7 \%$ in 2009 (Fig. 18). As Fig. 18 suggests and Fig. 19 demonstrates, throughout the data series, national agricultural production in Kuwait is consistently lower than the imported component. The 1986-1990 period indicates particularly low internal blue-water intensity, suggesting that there exist behaviours that can reduce pressure on internal water resources.

Fig. 18Kuwait: Percentage Food Tonnage Imports and Blue Water Imports 


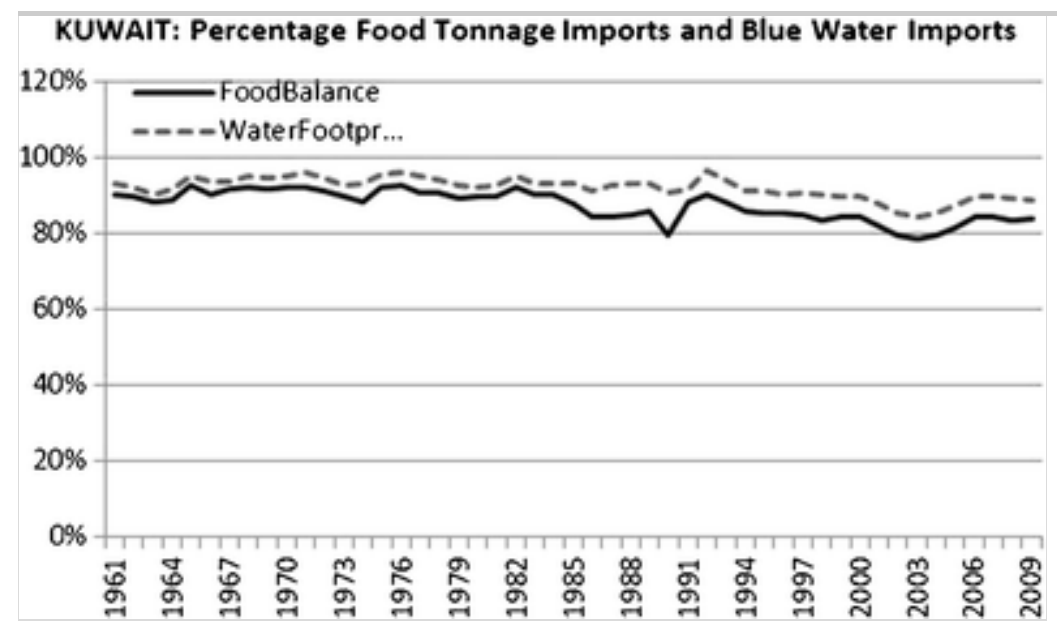

Fig. 19 Kuwait Blue Water Intensity

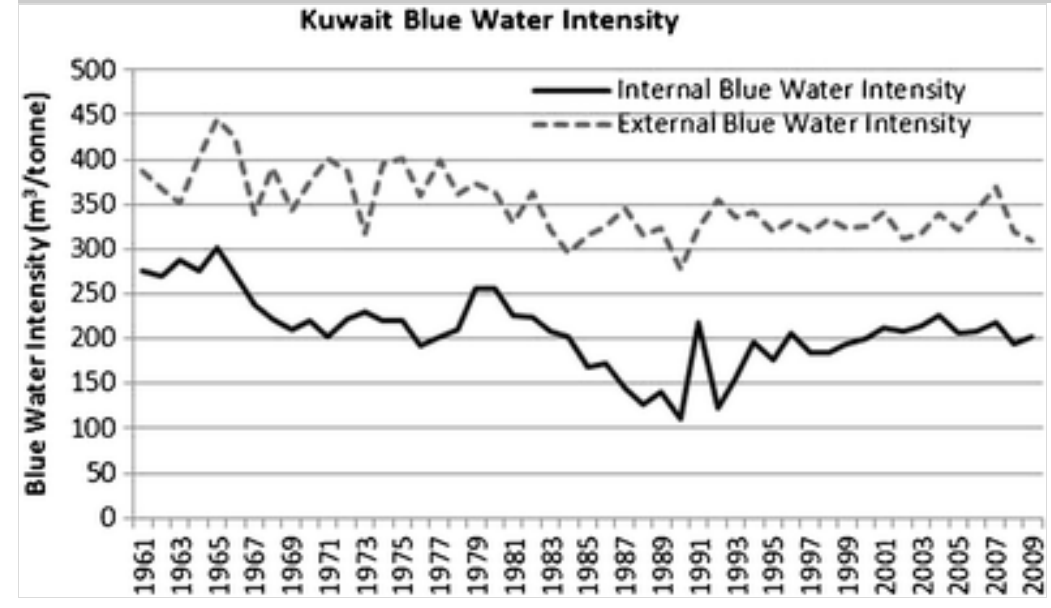

The most water intensive agricultural products in Kuwait are 'Dates' at $1837 \mathrm{~m}^{3} / \mathrm{t}$ (global average $1283 \mathrm{~m}^{3} / \mathrm{t}$ ) and 'Meat, Other' at $1441 \mathrm{~m}^{3} / \mathrm{t}$ (global average $\left.637 \mathrm{~m}^{3} / \mathrm{t}\right)$. The largest water users in 2009 were 'Dates' (29.4MCM, intensity $\left.1837 \mathrm{~m}^{3} / \mathrm{t}\right)$ and 'Vegetables, Other' (22.9MCM, intensity $\left.134 \mathrm{~m}^{3} / \mathrm{t}\right)$.

\section{Lebanon}

Lebanon has no identifiable decoupling, with a variable percentage of food imports seen over the available time series. Unlike other MENA countries, there is no strong difference between external food percentages and external blue water percentages, except for 10 years from the mid-1980s to mid-1990s (Fig. 20). As shown in the intensity graphs of Fig. 21, the average blue water intensity of internal and external food production for Lebanon up to 1985 was identical at $328 \mathrm{~m}^{3} / \mathrm{t}$, and from 2002 at $333 \mathrm{~m}^{3} / \mathrm{t}$. Only between 1986 and 2001 
does water intelligent food trade manifest itself, with external water intensity averaging $347 \mathrm{~m}^{3} / \mathrm{t}$ and internal intensity $284 \mathrm{~m}^{3} / \mathrm{t}$. The historic evidence for a divergence in internal and external blue water intensities suggests potential for a longer-term strategic deployment of water-intelligent food trade to reduce pressure on internal blue water resources.

Fig. 20 Lebanon: Percentage Food Tonnage Imports and Blue Water Imports

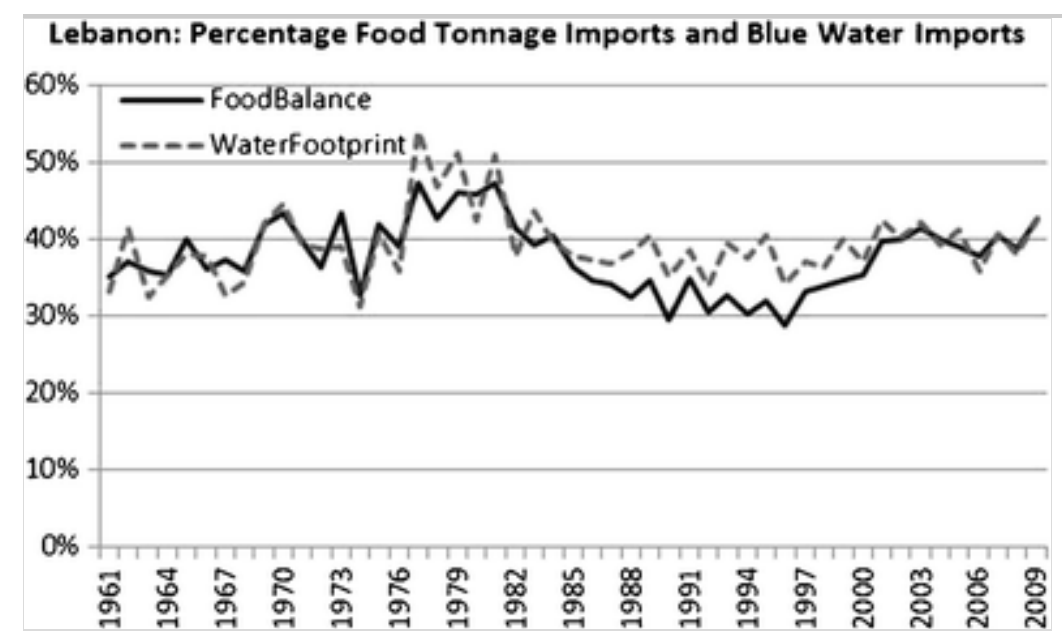

Fig. 21Lebanon Blue Water Intensity

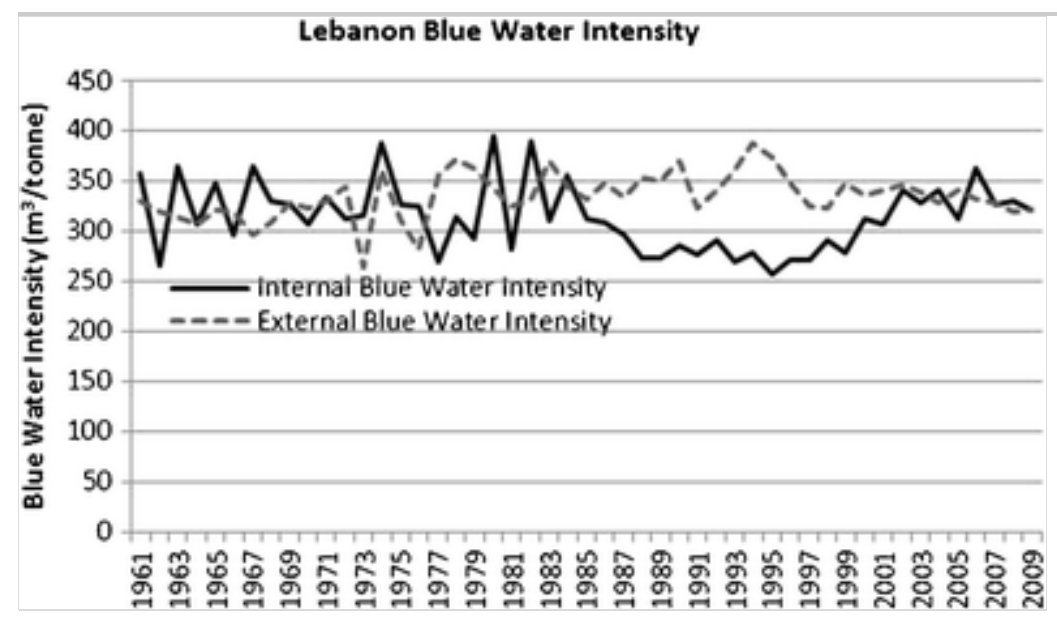

The most water-intensive Lebanese agricultural products are 'Olive Oil' at $5828 \mathrm{~m}^{3} / \mathrm{t}$ (global average $2388 \mathrm{~m}^{3} / \mathrm{t}$ ) and 'Sesameseed Oil' at $3784 \mathrm{~m}^{3} / \mathrm{t}$ (global average $1183 \mathrm{~m}^{3} / \mathrm{t}$ ). The largest agricultural water users in 2009 were 'Poultry Meat' at 222MCM (intensity $1632 \mathrm{~m}^{3} / \mathrm{t}$ ) and 'Fruits, Other' at 171.8MCM (intensity $747 \mathrm{~m}^{3} / \mathrm{t}$ ). 


\section{Libya}

Libya commenced decoupling prior to 1961 and, by stabilisation in 1970, had increased i food imports from $35 \%$ in 1961 to $58.75 \%$ (Fig. 22). During the same period, blue water imports had risen from $18 \%$ of national needs to averaging $46.44 \%$ from 1970 onwards. Despite the relatively high proportion of food imports, and opportunities therefore for importing the most waterintensive elements of production, Libya appears not to have embraced water intelligent food trade. However this anomaly can be partly explained by the unusually high water intensity of Libyan internal production, compared to many other MENA countries, which suggests efforts in Libya should be focused on reducing intensity of internal agricultural water use. The water intensity plots in Fig. 23 do show decline in internal blue water intensity from $1304 \mathrm{~m}^{3} / \mathrm{t}$ in 1961 to $726 \mathrm{~m}^{3} / \mathrm{t}$ by 2009 , but remain high compared to many other countries. Figure 23 also shows a decline in external blue water intensity from $534 \mathrm{~m}^{3} / \mathrm{t}$ in 1961 to $381 \mathrm{~m}^{3} / \mathrm{t}$ by 2009 .

Fig. 22 Libya: Percentage Food Tonnage Imports and Blue Water Imports

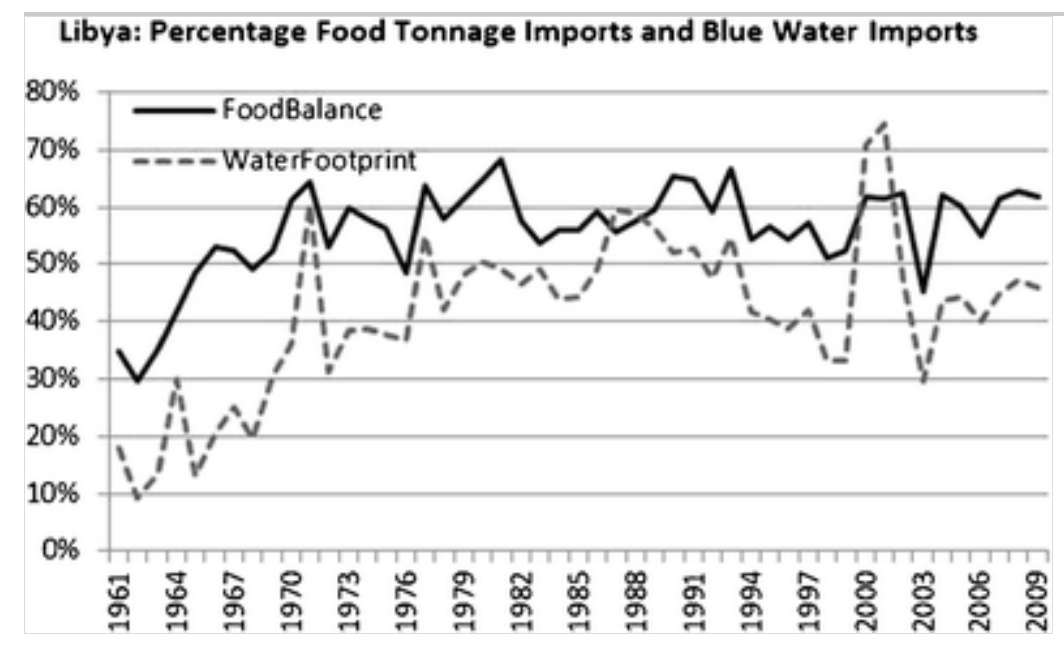

Fig. 23 Libya Blue Water Intensity 


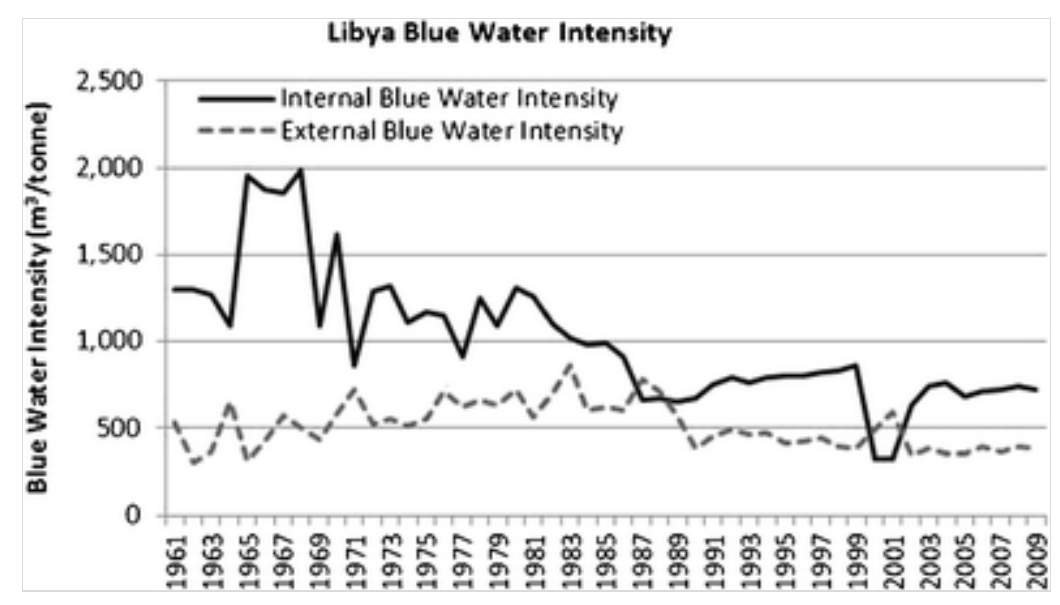

The most intense water user in Libya in 2009 was 'Meat, Other' at $19,308 \mathrm{~m}^{3} / \mathrm{t}$ (global average $637 \mathrm{~m}^{3} / \mathrm{t}$ ), followed by Olive Oil as the largest plant-based product at $16,204 \mathrm{~m}^{3} / \mathrm{t}\left(2388 \mathrm{~m}^{3} / \mathrm{t}\right)$. The largest uses of agriculture blue water in 2009 were Olives (576MCM at $3317 \mathrm{~m}^{3} / \mathrm{t}$ ) and Olive Oil (275MCM, 16,204 $\left.\mathrm{m}^{3} / \mathrm{t}\right)$.

\section{Morocco}

As with Lebanon, Morocco's percentage food imports and percentage blue water imports closely track each other. Prior to decoupling in 1977, Morocco imported $12.42 \%$ of its food needs and $10.97 \%$ of its blue water needs. By 2009, Morocco was importing $21.27 \%$ of its food and $23.47 \%$ of its blue water needs (Fig. 24). Figure 25 shows that internal and imported water intensities are generally within $50 \mathrm{~m}^{3} / \mathrm{t}$ of each-other and follow an identical trajectory of decline up to 1985 followed by increase to 2009. In 1961 internal intensity was $447 \mathrm{~m}^{3} / \mathrm{t}$ while external intensity was $278 \mathrm{~m}^{3} / \mathrm{t}$. By 2009 internal intensity was $310 \mathrm{~m}^{3} / \mathrm{t}$ and external intensity was $352 \mathrm{~m}^{3} / \mathrm{t}$. There would appear to be scope to substitute internal water intensity for imports.

Fig. 24 Morocco: Percentage Food Tonnage Imports and Blue Water Imports 


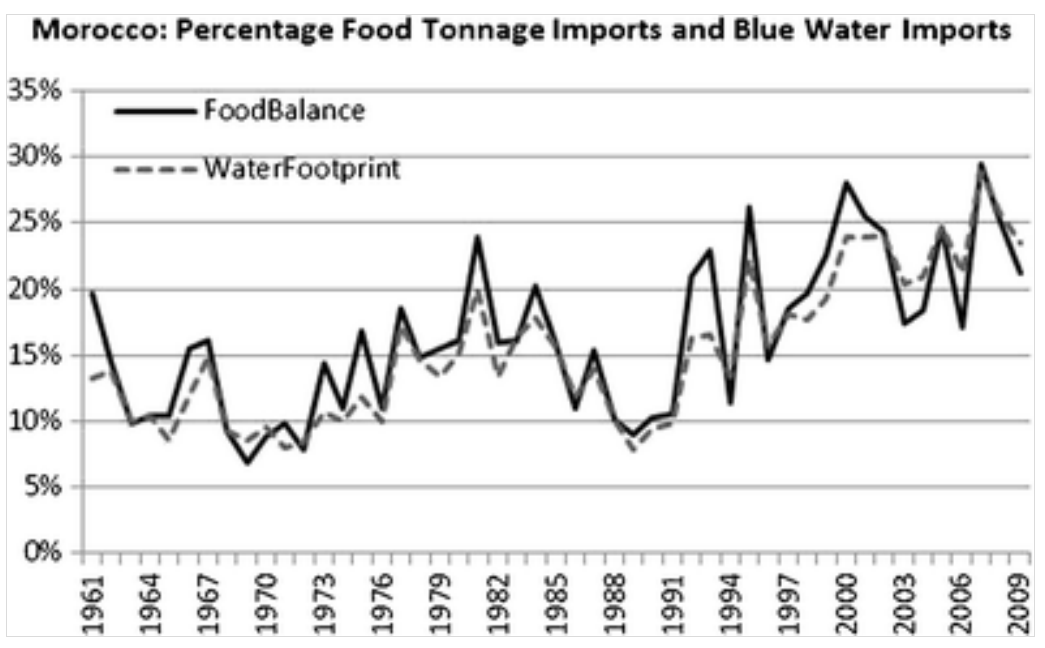

Fig. 25 Morocco Blue Water Intensity

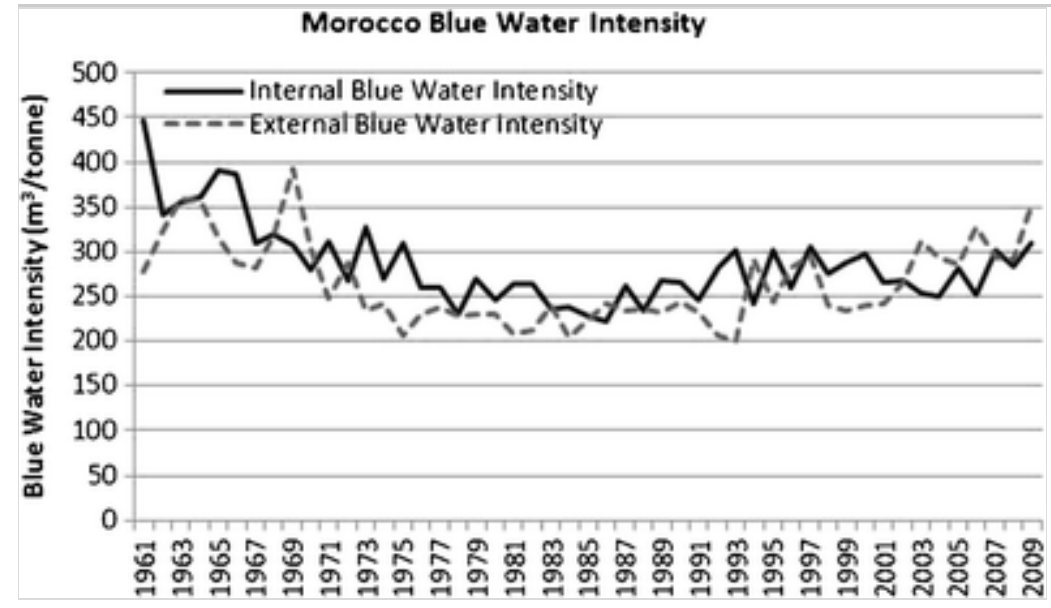

Morocco's most water intensive agricultural products in 2009 were 'Meat, Other' at 19,628 $\mathrm{m}^{3} / \mathrm{t}$ (global average $637 \mathrm{~m}^{3} / \mathrm{t}$ ), followed by 'Olive Oil' at $6533 \mathrm{~m}^{3} / \mathrm{t}$ (global average $2388 \mathrm{~m}^{3} / \mathrm{t}$ ). The largest agricultural water users were 'Meats, Other' requiring $1217 \mathrm{MCM}$ of water (at $19,628 \mathrm{~m}^{3} / \mathrm{t}$ ) and 'Olives' requiring $1136 \mathrm{MCM}$ (at $1137 \mathrm{~m}^{3} / \mathrm{t}$ ).

\section{Saudi Arabia}

Saudi Arabia has an observable decoupling from around 1976, with a rapid doubling of imports up to 1982 driven by a rise in cereal imports. Increases in domestic wheat production from 1980 resulted in imports as a percentage of total food declining (although cereal imports did continue to increase). From the early 1990s a gradual upward trend in decoupling resumed; as of 2009 food imports comprised $67.9 \%$ of total food needs, up from $36 \%$ in 1961 (Fig. 26). In contrast, blue water from imports comprised $23.7 \%$ in 1961 and $48.4 \%$ in 2009. Despite its significant water scarcity and dependence on 
fossil aquifers, Saudi Arabia appears not to be embracing water-intelligent food trade.

Fig. 26 Saudi Arabia: Percentage Food Tonnage Imports and Blue Water Imports

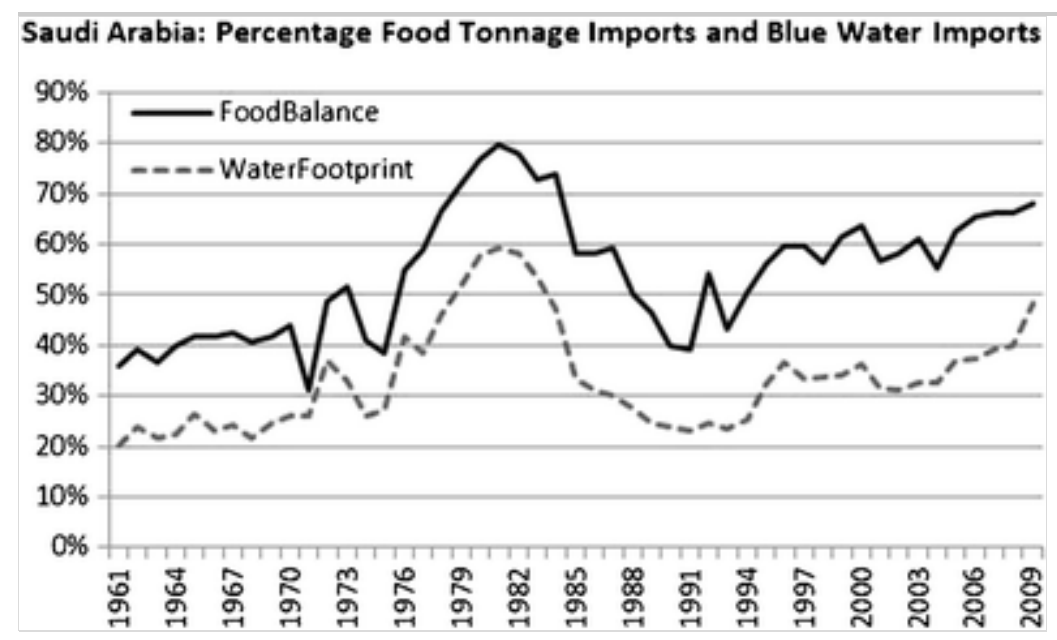

Figure 27 demonstrates that both internal and external production water intensities have declined. Internal water intensity has dropped form $1350.4 \mathrm{~m}^{3} / \mathrm{t}$ in 1961 to $738.2 \mathrm{~m}^{3} / \mathrm{t}$ by 2009 . External water intensity has dropped from 602.7 to $326.5 \mathrm{~m}^{3} / \mathrm{t}$ by 2009 . The water intensity of imports is therefore less than half that of internal production and there would appear considerable scope for use of trade to reduce pressure on internal blue-water resources.

Fig. 27 Saudi Arabia Blue Water Intensity

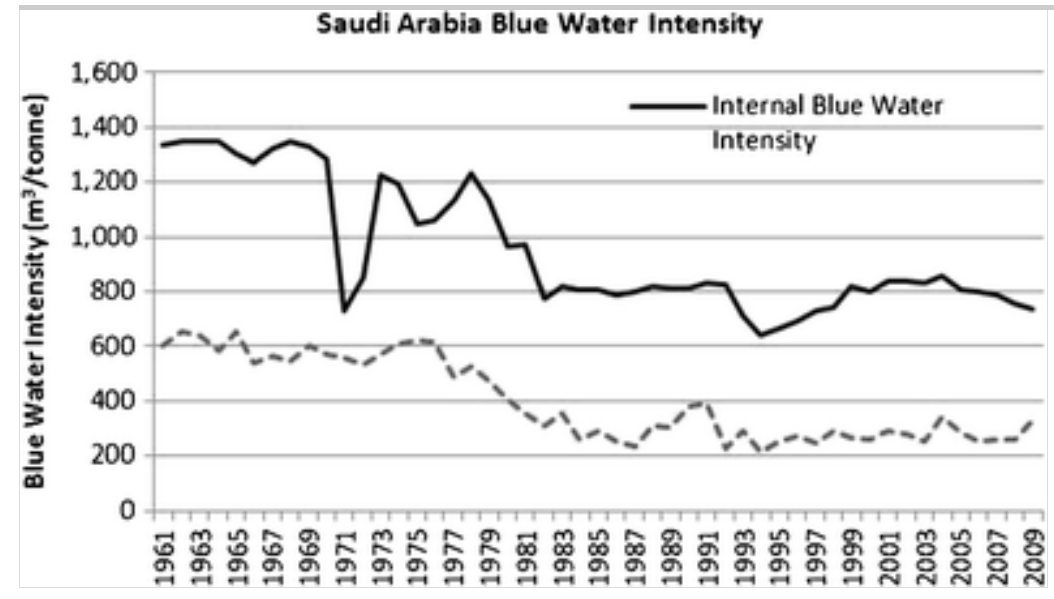

As of 2009 , the most water intensive agricultural products are 'Meat, Other' 
at $4666 \mathrm{~m}^{3} / \mathrm{t}$ (global average $637 \mathrm{~m}^{3} / \mathrm{t}$ ), followed by 'Sesameseed Oil' at $3724 \mathrm{~m}^{3} / \mathrm{t}$ (global average $1138 \mathrm{~m}^{3} / \mathrm{t}$ ). The largest water users are 'Dates' $\left(3017 \mathrm{MCM}\right.$ at $\left.3041 \mathrm{~m}^{3} / \mathrm{t}\right)$ and 'Wheat' $\left(1189 \mathrm{MCM}\right.$ at $\left.1032 \mathrm{~m}^{3} / \mathrm{t}\right)$, a legacy of policies of wheat irrigation production expansion in the 1980s.

\section{Syria}

Syria only exhibits statistically robust decoupling from 2002. From 1961 to 2002 , there was significant inter-annual variation in imports of over $10 \%$. Imported blue water as a percentage of total blue water needs closely matches and tracks total food imports. Between 1961 and 2002, food imports averaged $14.1 \%$ of total food needs, with blue water averaging $16.2 \%$. By 2009 food imports were $31.8 \%$ and blue water imports were $32 \%$ (Fig. 28).

Fig. 28 Syria: Percentage Food Tonnage Imports and Blue Water Imports

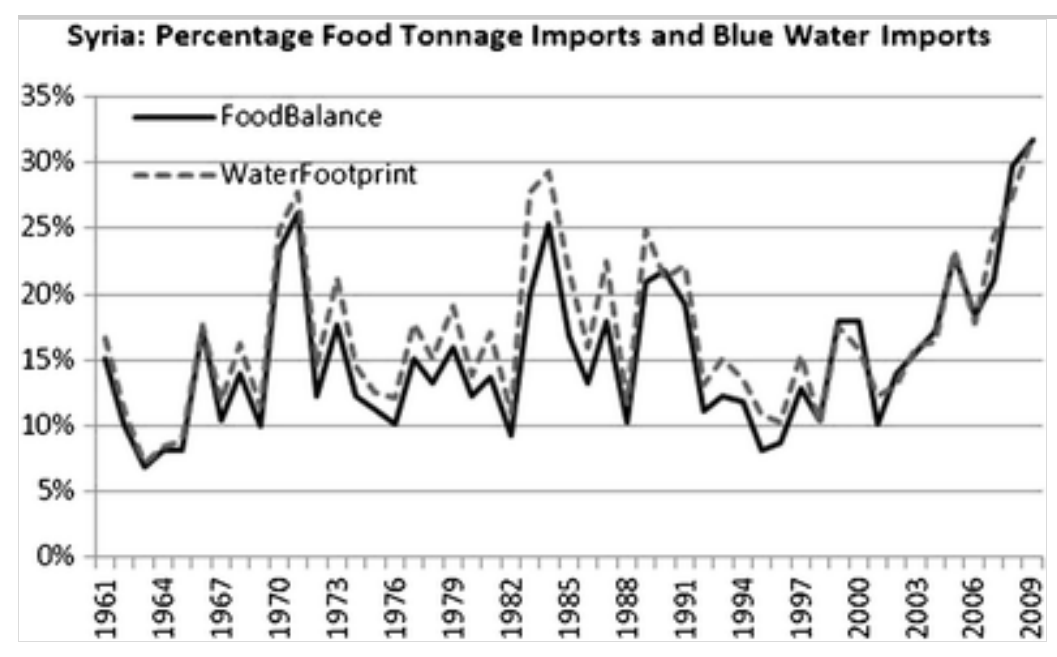

Prior to decoupling, the blue water intensity of Syria's food imports were generally higher than its internal production at $472 \mathrm{~m}^{3} / \mathrm{t}$ versus $404 \mathrm{~m}^{3} / \mathrm{t}$. Just prior to decoupling, the intensity of food imports decreased and internal production intensity increased, and from 2002 to 2009 external and internal water intensities were, on average $442 \mathrm{~m}^{3} / \mathrm{t}$ and $445 \mathrm{~m}^{3} / \mathrm{t}$ respectively. There would therefore appear to be scope to restore high intensity imports and reduce pressure on internal blue water resources in future (Fig. 29).

Fig. 29 Syria Blue Water Intensity 


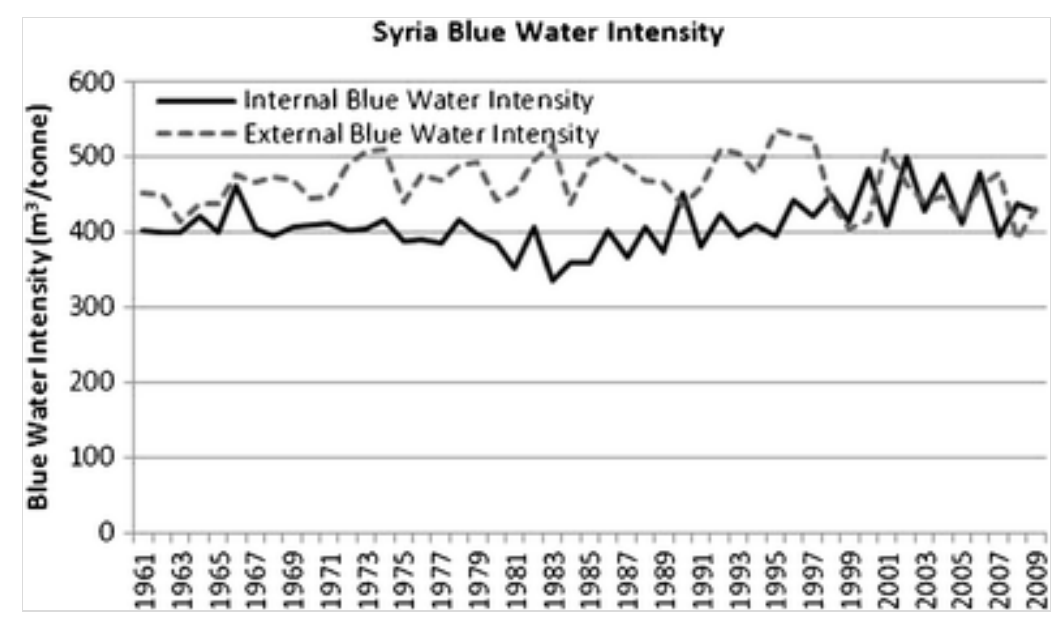

AQ6

The most intense agricultural products in Syria are 'Spices, Other' at $9574 \mathrm{~m}^{3} / \mathrm{t}$ (global average $715 \mathrm{~m}^{3} / \mathrm{t}$ ) and 'Meat, Other' at $8972 \mathrm{~m}^{3} / \mathrm{t}$ (global average $637 \mathrm{~m}^{3} / \mathrm{t}$ ). In 2009 the largest water users were 'Wheat' at $1647 \mathrm{MCM}$ (intensity $445 \mathrm{~m}^{3} / \mathrm{t}$ ) and 'Olive Oil' at 1104.47MCM $\left(5813 \mathrm{~m}^{3} / \mathrm{t}\right)$.

\section{Tunisia}

Prior to its decoupling in 1978, Tunisia exhibited a dynamic trend in food imports, with imported food average $16.5 \%$ of total needs per year. Blue water imports were $10 \%$. A general upward trend is visible after 1978 with continued interannual variation. In 2009, food imports comprised $25.3 \%$ (down from $32.3 \%$ the previous year), while blue water comprised $21.6 \%$ (Fig. 30). Despite its decoupling, Tunisia appears not to have embraced water-intelligent food trade, with significant potential to further the waterimpact of the decoupling trend by focusing imports on more water-intensive food needs.

Fig. 30 Tunisia: Percentage Food Tonnage Imports and Blue Water Imports 


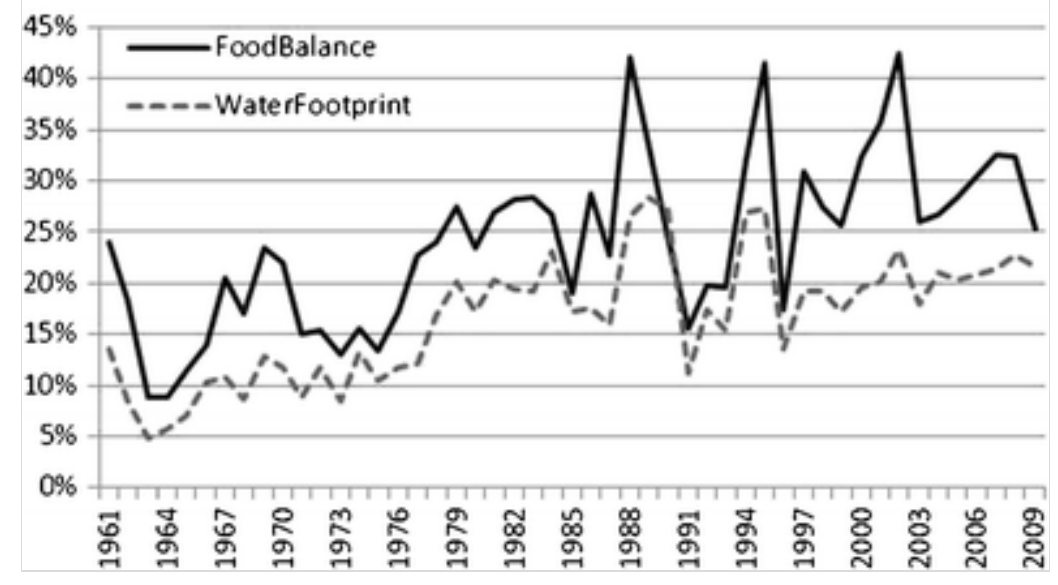

Tunisia's internal water intensity decreased markedly from 1961 to the early 1980s. By 2009 it was $295.7 \mathrm{~m}^{3} / \mathrm{t}$. Tunisia's external blue water intensity has continuously fluctuated, averaging $231.4 \mathrm{~m}^{3} / \mathrm{t}$ between 1961 and 2009 (Fig. 31). There would appear to be scope to decrease internal blue water intensity through trade.

Fig. 31 Tunisia Blue Water Intensity

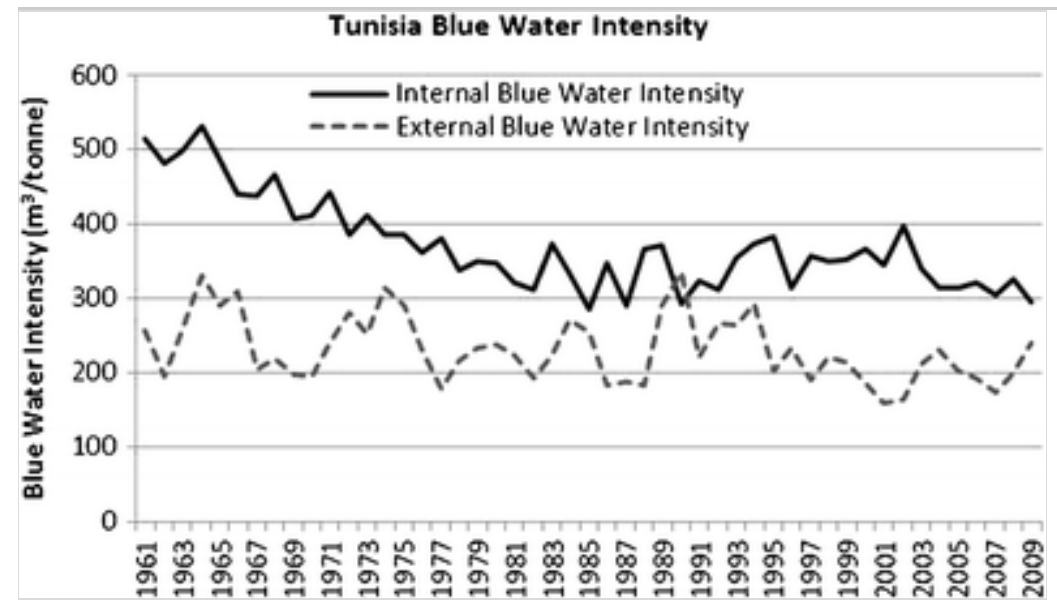

The most water intensive agricultural products in Tunisia are 'Meats, Other' requiring $59,180 \mathrm{~m}^{3} / \mathrm{t}$ (global average $637 \mathrm{~m}^{3} / \mathrm{t}$ ), followed by 'Oats' at $13,487 \mathrm{~m}^{3} / \mathrm{t}$ (global average $181 \mathrm{~m}^{3} / \mathrm{t}$ ). The largest water users are 'Meats, Other' requiring $592 \mathrm{MCM}\left(59,180 \mathrm{~m}^{3} / \mathrm{t}\right)$ of water in 2009 , with 'Dates' requiring $530 \mathrm{MCM}$ (at $3271 \mathrm{~m}^{3} / \mathrm{t}$ ).

\section{United Arab Emirates}

The UAE decoupled prior to 1961, and has experienced a steady increase in percentage of imported foods since then, increasing rapidly to 1976, declining 
to 2000 , then rising again. Throughout the period up to 2000 , blue water imports were proportionally higher than food imports, although the difference has continuously declined. In 1961 the $27.6 \%$ of UAE's food derived from imports contained $53.7 \%$ of its blue water needs. By 1988, $82.3 \%$ of food needs contained $85.9 \%$ of blue water, but from 2001 percentage blue water needs met through trade was lower than tonnage through trade. By 2009 the $87.9 \%$ of food derived from imports contained $83.82 \%$ of UAEs blue water (Fig. 32).

Fig. 32United Arab Emirates: Percentage Food Tonnage Imports and Blue Water Imports

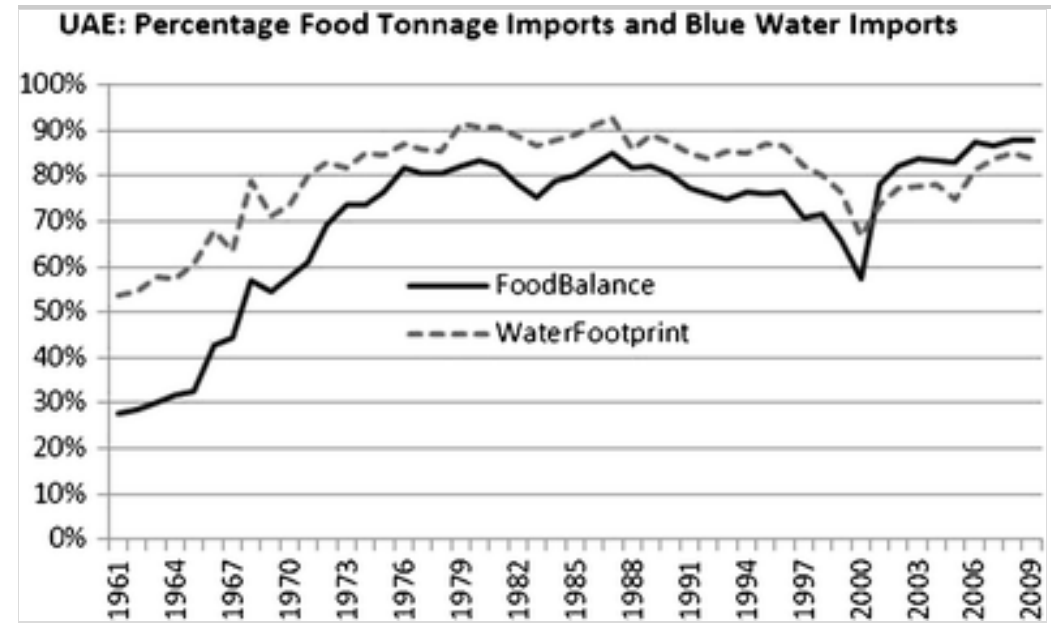

Figure 33 demonstrates the reversal in water-intelligent food trade. From 2000, there was a significant jump in internal blue water intensity. Prior to 2001 , internal water intensity had exhibited a slight decline from $438 \mathrm{~m}^{3} / \mathrm{t}$ in 1961 , being calculated as $369 \mathrm{~m}^{3} / \mathrm{t}$ in 2000 . By 2009, internal intensity was a record high of $788 \mathrm{~m}^{3} / \mathrm{t}$. External blue water intensity declined from $1327 \mathrm{~m}^{3} / \mathrm{t}$ in 1961 to $563 \mathrm{~m}^{3} / \mathrm{t}$ in 2009 .

Fig. 33 United Arab Emirates Blue Water Intensity 


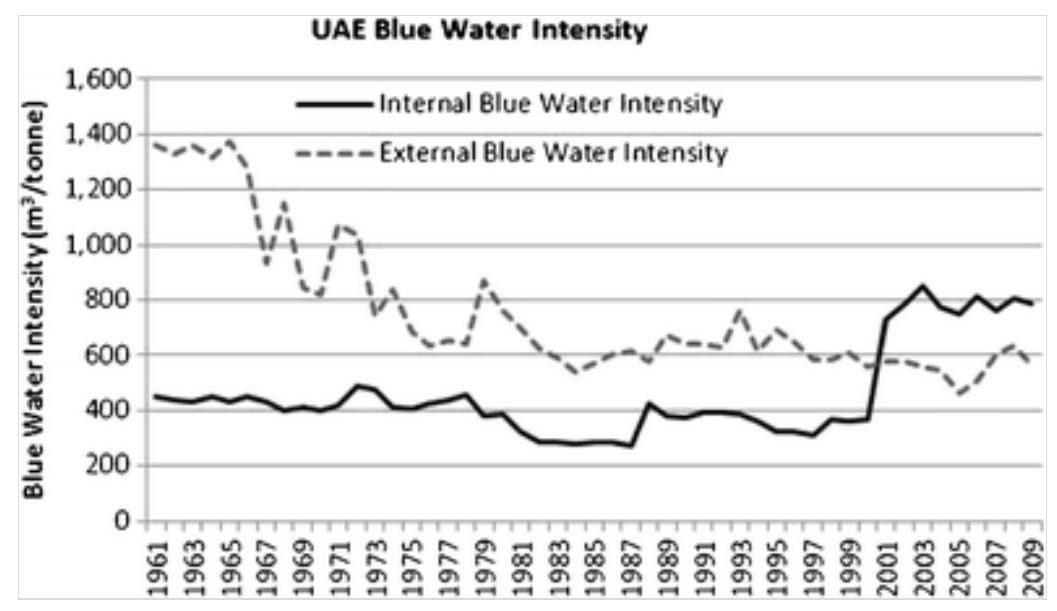

There were some multiple simultaneous changes in the Food Balance data at the turn of the millennium. Between 1998 and 2000 there was a near tripling of Date production. Over the same period there was a 6-fold increase in Vegetables, which dropped back after 2000. After 2000 Soybean and Groundnut Oils emerged strongly from a previously nil production. Detailed interrogation of water footprint food balances and tonnages showed that in 2000 the sudden increase in vegetable tonnage moderated the internal water intensity. The rise in water intensity in 2001 was caused by the reduced tonnages of vegetables, revealing the true water impact of Date production.

As of 2009, and uniquely for the MENA region, all the largest water intensities were animal derived, with 'Fats, Animals, Raw' at $2398 \mathrm{~m}^{3} / \mathrm{t}$ (global average $465 \mathrm{~m}^{3} / \mathrm{t}$ ), 'Butter, Ghee' at $2398 \mathrm{~m}^{3} / \mathrm{t}$ (global average $465 \mathrm{~m}^{3} / \mathrm{t}$ ) and 'Bovine Meat' at $2059 \mathrm{~m}^{3} / \mathrm{t}$ (global average $\left.550 \mathrm{~m}^{3} / \mathrm{t}\right)$. Largest blue water users were 'Dates' at $1241 \mathrm{MCM}$ (intensity $1635 \mathrm{~m}^{3} / \mathrm{t}$ ) and 'Meats, Other' at $41.43 \mathrm{MCM}$ (intensity $1381 \mathrm{~m}^{3} / \mathrm{t}$ ) demonstrating the significant resources being directed at Dates above all other produce.

\section{Yemen}

The data suggest that Yemen decoupled in 1964 (Fig. 34). From 1961 to 1963 near steady-state proportions were observed, with average food imports of $15.3 \%$ of annual food needs. From 1964 the percentage of foods met from imports steadily increased, barring a hiatus 1970-6 and rapid increase 1977-8 which appeared to fully restore the previous trend. By 2009, food imports comprised $60.9 \%$ of annual food needs. Over the same period, the external contribution of Yemen's blue water needs rose from 12.7 to $53.6 \%$, suggesting that Yemen is not embracing water-intelligent food trade.

Fig. 34 Yemen: Percentage Food Tonnage Imports and Blue Water Imports 


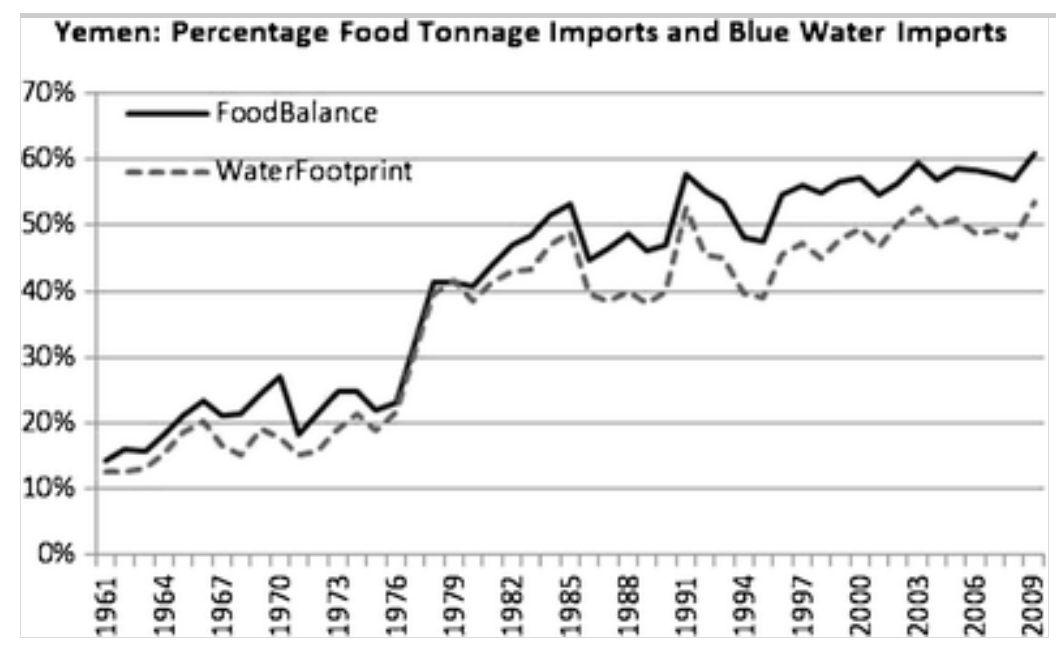

The water intensity plots in Fig. 35 further illustrates the lesser intensity of imports compared to internal production (lack of water intelligent trade). However, as with Libya, it is the high water intensity of internal production, rather than low intensity of external production, which has created the observed trends. Internal blue water intensity declined from $1005 \mathrm{~m}^{3} / \mathrm{t}$ in 1961 to $752 \mathrm{~m}^{3} / \mathrm{t}$ in 2009 and external blue water intensity decreased from 868 to $559 \mathrm{~m}^{3} / \mathrm{t}$.

Fig. 35Yemen Blue Water Intensity

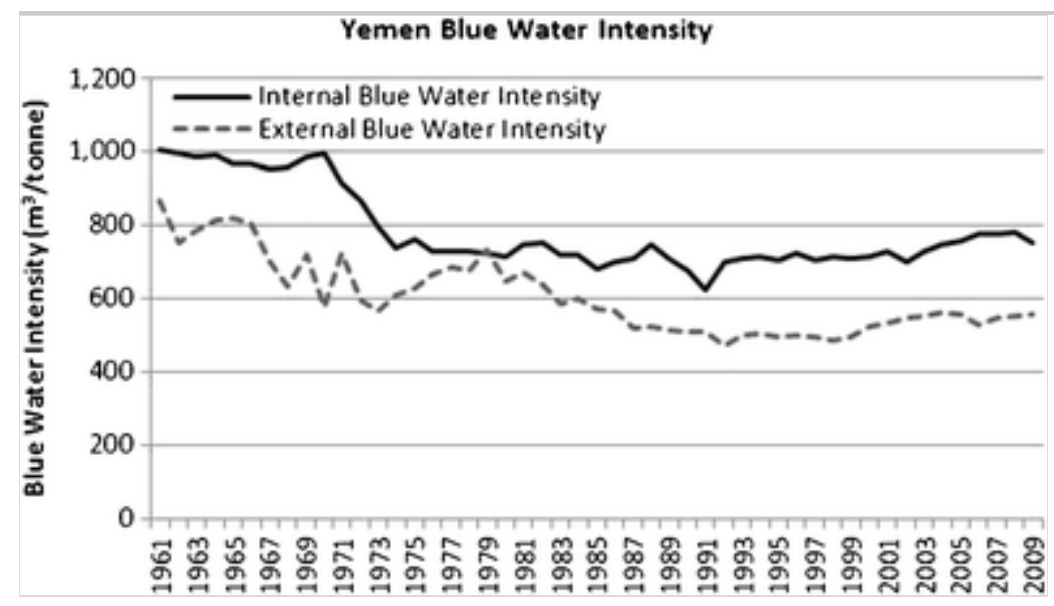

The most water intensive agricultural products in Yemen in 2009 were 'Coffee' at $15,450 \mathrm{~m}^{3} / \mathrm{t}$ (global average $116 \mathrm{~m}^{3} / \mathrm{t}$ ), followed by 'Butter, Ghee' at $5587 \mathrm{~m}^{3} / \mathrm{t}$ (global average $465 \mathrm{~m}^{3} / \mathrm{t}$ ). The largest water users were 'Poultry Meat' requiring $458 \mathrm{MCM}$ of water (intensity $3268 \mathrm{~m}^{3} / \mathrm{t}$ ) and 'Fruits, Other' requiring 339MCM (intensity $698 \mathrm{~m}^{3} / \mathrm{t}$ ). 


\section{Discussion}

The analysis above has illustrated how internal and external food production and blue water contributions have changed from 1961 to 2009 in 1514 MENA economies. It has allowed identification of the most intensive water users in the MENA and also the largest total water use in agricultural production. Both these indicators could be significant for policymakers and managers in determining opportunities for food trade and imported agricultural production to reduce pressure on some of the scarcest blue water resources in the world. HEleven of the most intensive blue water crops in the MENA countries analysed have intensities above the global average. There would appear to be a significant role for imports not only to reduce blue water demands in the MENA region, but if grown in green water intensive areas, to reduce net global blue water use.

The two tables below highlight the most water-intensive products and largest water users across the countries analysed. Due to the methodological limitations on double counting discussed above, animal-derived produce are excluded from these tables. The tables also shade (in grey) those countries where water-intelligent food trade is not, as of 2009 apparent. This is to highlight the largest opportunities to deliver net improvements in MENA blue-water availability.

Table 2 shows the 40 largest non-animal agricultural water users in the MENA by absolute volume and country. In 2009, a combination of Food Balance and Water Footprint data suggests that the MENA region used 99.79 Billion Cubic Meters. The first 15 crops listed in Table 2 comprise over $50 \%$ of the total water used in the region. Of those 15 crops, all but Saudi Arabian Dates are produced in countries already deploying water-intelligent food trade. 


\begin{tabular}{|c|c|c|c|c|}
\hline \multirow{2}{*}{$\begin{array}{l}\text { Crop } \\
\text { Wheat }\end{array}$} & \multirow{2}{*}{$\begin{array}{l}\begin{array}{l}2009 \\
\text { tonnage } \\
\text { ('000t) }\end{array} \\
13484\end{array}$} & \multirow{2}{*}{$\begin{array}{l}\begin{array}{l}2009 \\
\text { water } \\
\left({ }^{\prime} 000 \mathrm{~m}^{3}\right)\end{array} \\
9937708\end{array}$} & \multicolumn{2}{|c|}{ Water Intensity } \\
\hline & & & 737 & Iran \\
\hline Rice (Milled Equivalent) & 3682 & 5802832 & 1576 & Egypt \\
\hline Maize & 7686 & 5480118 & 713 & Egypt \\
\hline Wheat & 8523 & 5028570 & 590 & Egypt \\
\hline Fruits, Other & 4008 & 3911808 & 976 & Iran \\
\hline Rice (Milled Equivalent) & 1503 & 3407301 & 2267 & Iran \\
\hline Dates & 992 & 3016672 & 3041 & Saudi Arabia \\
\hline Fruits, Other & 2048 & 2555904 & 1248 & Egypt \\
\hline Dates & 1023 & 2333463 & 2281 & Iran \\
\hline Vegetables, Other & 10711 & 2013668 & 188 & Iran \\
\hline Sugar Cane & 15482 & 1826876 & 118 & Egypt \\
\hline Oranges, Mandarins & 3182 & 1731008 & 544 & Egypt \\
\hline Vegetables, Other & 8671 & 1716858 & 198 & Egypt \\
\hline Tomatoes & 5888 & 1672192 & 284 & Iran \\
\hline Wheat & 3702 & 1647390 & 445 & Syria \\
\hline Apples & 2000 & 1550000 & 775 & Iran \\
\hline Tomatoes & 10279 & 1521292 & 148 & Egypt \\
\hline Pulses, Other & 326 & 1378980 & 4230 & Iran \\
\hline Dates & 601 & 1372684 & 2284 & Algeria \\
\hline Dates & 759 & 1240965 & 1635 & UAE \\
\hline Tea & 166 & 1204496 & 7256 & Iran \\
\hline Wheat & 1152 & 1188864 & 1032 & Saudi Arabia \\
\hline Olives & 850 & 1136450 & 1337 & Morocco \\
\hline Oranges, Mandarins & 2276 & 1131172 & 497 & Iran \\
\hline Olive Oil & 190 & 1104470 & 5813 & Syria \\
\hline Olives & 886 & 1054340 & 1190 & Syria \\
\hline Potatoes & 4108 & 1047540 & 255 & Iran \\
\hline Potatoes & 3659 & 1035497 & 283 & Egypt \\
\hline Wheat & 6371 & 962021 & 151 & Morocco \\
\hline Maize & 1643 & 906936 & 552 & Iran \\
\hline Sugar Beet & 5334 & 880110 & 165 & Egypt \\
\hline Fruits, Other & 873 & 864270 & 990 & Morocco \\
\hline Sugar (Raw Equivalent) & 1749 & 795795 & 455 & Egypt \\
\hline Olives & 500 & 768000 & 1536 & Egypt \\
\hline Sugar Beet & 2016 & 697536 & 346 & Iran \\
\hline Olive Oil & 101 & 659833 & 6533 & Morocco \\
\hline Olives & 171 & 567207 & 3317 & Libya \\
\hline Sorghum & 244 & 567056 & 2324 & Saudi Arabia \\
\hline Grapes & 493 & 565471 & 1147 & Algeria \\
\hline Fruits, Other & 783 & 541053 & 691 & Algeria \\
\hline
\end{tabular}

\section{Table 2}

The 50 largest non-animal-derived agricultural produce in the MENA, by crop type and country. Crops from countries not adopting water-intelligent food trade in 2009 are highlighted in grey 
Dates and olive-derived products comprise a number of major crops, and are unlikely to be suitable for substitution by tropical produce. However, $40 \%$ of the 2009 crop water use is accounted for by staple crops produced across the MENA. These are (in order of decreasing amount) Wheat, Rice, Maize, Pulses, Potatoes and Barley. Isolating just those countries not presently engaged in water-intelligent food trade, staples account for $23 \%$ of internal blue water. In those same countries, by contrast, dates account for $26 \%$ of blue water. This finding suggests that tropical production of staple crops could have a significant impact on MENA blue water security and environmental health.

Table 3 presents the top 40 most water-intensive crop products. Unlike the greatest water users, many of the most intensive crops are produced in countries currently not embracing water-intelligent food trade. The top 40 crops listed however only comprise $11.7 \%$ of total MENA water use in 2009. In addition, the occurrence of Olive and Olive Oil crops, in addition to dates means that substitution of these specialist Mediterranean crops by tropical imports may not be easily achievable or desirable. Similarly, the social and livelihood impacts of directly challenging traditional regional crops must be considered. Therefore further decoupling in the MENA is probably not best achieved through prioritising the most water-intensive agricultural products, but rather by targeting the greatest total water users. 


\begin{tabular}{|c|c|c|c|c|}
\hline Crop & $\begin{array}{l}2009 \\
\text { tonnage } \\
\text { ('000t) }\end{array}$ & $\begin{array}{l}2009 \\
\text { water } \\
\left({ }^{\prime} 000 \mathrm{~m}^{3}\right)\end{array}$ & \multicolumn{2}{|c|}{ Water Intensity } \\
\hline Olive Oil & 17 & 275468 & 16204 & Libya \\
\hline Coffee & 19 & 293550 & 15450 & Yemen \\
\hline Olive Oil & 1 & 14092 & 14092 & Iran \\
\hline Oats & 1 & 13497 & 13497 & Tunisia \\
\hline Spices, Other & 33 & 315942 & 9574 & Syria \\
\hline Oilcrops Oil, Other & 3 & 23451 & 7817 & Israel \\
\hline Olive Oil & 7 & 52507 & 7501 & Egypt \\
\hline Pimento & 3 & 22314 & 7438 & Iran \\
\hline Sesameseed Oil & 1 & 7336 & 7336 & Syria \\
\hline Tea & 166 & 1204496 & 7256 & Iran \\
\hline Spices, Other & 22 & 156002 & 7091 & Egypt \\
\hline Olive Oil & 101 & 659833 & 6533 & Morocco \\
\hline Olive Oil & 13 & 75764 & 5828 & Lebanon \\
\hline Olive Oil & 190 & 1104470 & 5813 & Syria \\
\hline Olive Oil & 18 & 93474 & 5193 & Jordan \\
\hline Groundnut Oil & 16 & 79904 & 4994 & Egypt \\
\hline Pimento & 46 & 227286 & 4941 & Egypt \\
\hline Olive Oil & 54 & 236088 & 4372 & Algeria \\
\hline Oilcrops, Other & 3 & 12873 & 4291 & Israel \\
\hline Pulses, Other & 326 & 1378980 & 4230 & Iran \\
\hline Oats & 25 & 103700 & 4148 & Morocco \\
\hline Sesameseed Oil & 19 & 77102 & 4058 & Iran \\
\hline Sesameseed Oil & 4 & 15136 & 3784 & Lebanon \\
\hline Sesameseed Oil & 13 & 48412 & 3724 & Saudi Arabia \\
\hline Olive Oil & 12 & 44160 & 3680 & Israel \\
\hline Dates & 85 & 310250 & 3650 & Morocco \\
\hline Cereals, Other & 4 & 13960 & 3490 & Morocco \\
\hline Olives & 171 & 567207 & 3317 & Libya \\
\hline Dates & 162 & 529902 & 3271 & Tunisia \\
\hline Sesameseed Oil & 10 & 32060 & 3206 & Yemen \\
\hline Barley & 23 & 72795 & 3165 & Yemen \\
\hline Sesameseed & 8 & 25240 & 3155 & Syria \\
\hline Dates & 992 & 3016672 & 3041 & Saudi Arabia \\
\hline Groundnut Oil & 18 & 53298 & 2961 & Morocco \\
\hline Groundnuts (Shelled Eq) & 10 & 29230 & 2923 & Syria \\
\hline Sesameseed Oil & 4 & 11584 & 2896 & Jordan \\
\hline Olives & 40 & 115400 & 2885 & Iran \\
\hline Pimento & 1 & 2779 & 2779 & Syria \\
\hline Groundnuts (Shelled Eq) & 139 & 366404 & 2636 & Egypt \\
\hline Groundnut Oil & 6 & 14712 & 2452 & Lebanon \\
\hline
\end{tabular}

\section{Table 3}

The 40 largest non-animal-derived agricultural produce in the MENA, by crop type and country 


\section{Conclusion and further research}

This paper has used the concept and methodology of water resource decoupling to highlight how MENA economies have used trade to enhance their water security, and the potential that exists for these trends to be expanded. Given that global water resources are subject to spatial limitations rather than absolute scarcity, the paper has argued that the distinction between relative and absolute decoupling used in the general decoupling literature is not applicable to water. Rather a water-specific model of national water decoupling has been used that recognises the important role of food trade. The analysis has shown that considerable potential exists for certain countries in the MENA to adopt or further trends in water-intelligent food trade. Many of the major crops produced in the MENA region are produced at intensities above the global blue-water average, suggesting that trade could not only reduce MENA blue water but also provide net global reduction in blue water. The paper has established that some of the major MENA crops are native species (dates and olives) that are unsuitable for direct substitution by imports. In addition, the most water-intensive crops contribute, in total, a relatively small proportion of regional water use. However, calculations show that there is a considerable role for imports of staple crops from more waterabundant regions that could have a real and significant impact on blue water uses in the MENA region. Additionally, in the countries with the most waterintensive internal agricultural production, opportunities would appear to exist to improve national water productivity (although current political instability in Libya and Yemen will likely continue to preclude such measures in the medium term).

While it is acknowledged that food security and food trade policies are influenced by multiple political and economic criteria, this research demonstrates that enhanced strategic attention to water as a factor of production could assist with reducing future pressure on national water resources in water-scarce regions, including the MENA. Further research and analysis is required on trade-offs between local agricultural livelihoods and intentional decoupling policies, and the political balancing of local environmental and agricultural risk with exposure to risks of global trade and market volatility in staple crops. Further conceptual analysis is recommended on linking overall decoupling trends with decoupling of economic and agricultural output to inter-annual variation. Such work would enable a more holistic picture of water resource trends and constraints to be identified, with resultant avenues for new policy analysis and planning. 


\section{Acknowledgments}

The author acknowledges support from the IDRC-DFID PRISE consortium, funding the development of the methodology used in this paper through their small-grants programme hosted by the Overseas Development Institute (ODI). The author is also grateful to two anonymous reviewers for their helpful feedback.

\section{References}

Allan, J. A. (1997). 'Virtual water': a long term solution for water short Middle Eastern economies? Paper presented at the 1997 British Association Festival of Science, Roger Stevens Lecture Theatre, University of Leeds, Water and Development Session- TUE.51, 14.45, 9 September 1997. Available online: https://www.soas.ac.uk/water/publications/papers /file38347.pdf .

Allan, J. A. (1998). Virtual water: a strategic resource. Global solutions to regional deficits. Groundwater, 36(4), 545-546.

Allan, J. A. (2001). The Middle East Water Questions. London: I.B. Tauris.

Allan, J. A. (2011). Virtual Water: Tackling the threat to Our Planet's Most Precious Resource. London: I.B. Tauris.

Chapagain, A. K., \& Hoekstra, A. Y. (2008). The global component of freshwater demand and supply: an assessment of virtual water flows between nations as a result of trade in agricultural and industrial products. Water International, 33(1), 19-32.

de Fraiture, C., de Cai, X., Amarasinghe, U., Rosegrant, M., \& Molden, D. (2004). Does international cereal trade save water? The impact of virtual water trade on global water use (Comprehensive Assessment Research Report 4). Colombo: Comprehensive Assessment Secretariat. Available online: http://ageconsearch.umn.edu/bitstream/92832/2/CARR4.pdf .

Fadder, M., Gerten, D., Thammer, M., Heinke, J., Lotze-Campen, H., Lucht, W., \& Cramer, W. (2011). Internal and external green-blue agricultural water footprints of nations and related water and land savings through trade. Hydrology and Earth System Sciences Discussions, 8, 
FAO. (2001). Food Balance Sheets: A Handbook (Reprinted 2008). Rome. Available online: ftp://ftp.fao.org/docrep/fao/011/x9892e/x9892e00.pdf .

FAO. (2007). Coping With Water Scarcity: challenge of the twenty-first century. World Water Day 2007. Available at: www.fao.org/nr/water /docs/escarcity.pdf .

FAO. (2013). Food Balance Sheets 1961-2009. Accessed via http://faostat.fao.org/site/354/default.aspx . Downloaded 10 Feb 2014 (2009 data series now superseded).

Future Directions International. (2014). Food and Water Security: Our Global Challenge. Landmark Study. Dalkeith: Future Directions International.

Gilmont, M. (2014). Decoupling dependence on natural water: reflexivity in the regulation and allocation of water in Israel. Water Policy, 16(1), p79-p101.

Gilmont, M. (2015). Analysing the economic development impact of semi-arid lands, and mitigation by food-trade water resource decoupling (Working Paper). London: Overseas Development Institute.

Gilmont, M., \& Allan, J. A. (2014). Analysing Water Resource Decoupling through an Embedded Water time series using Water Footprint Data. Water Footprint Network Partner Projects in the Spotlight. Presented at World Water Week, 2 September.

Greco, F. (2014). Invisible 'Virtual Water Rivers': blinding transboundary interactions and consumers to the need for counter-hegemony. The Seventh International Workshop on Hydro-hegemony. UAE London 10-11 May 2014. Available online: http://www.uea.ac.uk/documents/40159 15624523/HH7+-+Greco+-+Invisible+Virtual+Water+Rivers.pdf/618242f5d87b-4f3d-b52a-c689d930a6c4 .

Grey, D., \& Sadoff, C. (2007). Sink or swim? Water security for growth and development. Water Policy, 9, 545-571. 
Hall, J.W., Grey, D., Garrick, D., Fung, E., Brown, C., Dadson, S. J., \& Sadoff, C. W. (2014). Coping with the curse of freshwater variability: institutions, infrastructure and information for adaptation. Science, $346(6208)$.

Heemskerk, J. (2014). Water usage from a long-term perspective: dependence on natural water has decoupled in Spain. MSc Dissertation, Department of Geography, King's College London.

Jackson, T. (2009). Prosperity Without Growth: Economics for a Finite Planet. London: Earthscan.

Jacobs, K., \& Sumner, D. A. (2002). The Food Balance Sheets of the Food and Agricultural Organization: A Review of Potential Ways to Broaden the Appropriate Uses of the Data. A Review Sponsored by FAO. UC Davis Agricultural Issues Centre.

Mekonnen, M. N., \& Hoekstra, A. Y. (2011). National Water Footprint Accounts: The Green, Blue and Grey Water Footprint of Production and Consumption (Value of Water Research Report Series No. 50). Delft: UNESCO/IHE.

MWI (Ministry of Water and Irrigation). (2012). Ministry of Water and Irrigation Annual Report. Jordan: Amman.

OECD. (2001). Decoupling environment from economic growth. OECD forum 14 May 2001: The transition to Sustainable Development: are we making progress in Decoupling Economic Growth from Environmental Degradation. Available at: http://www.oecdobserver.org/news/fullstory.php /aid/453/Decoupling_environment_from_economic_growth_.html .

Roson, R., \& Sartori, M., (2010). Water Scarcity and Vritual Water Trade in the Mediterranean. University Ca' Foscari of Venice, Dept. of Economics Research Paper Series No. 08_10.

State of Israel. (2002). Water in Israel: Consumption and Production 2001. Ministry of National Infrastructures, Water Commission.

State of Israel. (2005, 2008, 2013). Central Bureau of Statistics Annual Agriculture Accounts. Water Production and Consumption by Source and 
Purpose.

Steinberger, J. K., \& Roberts, J. T. (2010). From constraint to sufficiency: the decoupling of energy and carbon from human needs, 1975-2005. Ecological Economics, 70, 425-433.

Taha, S. (2006). Jordan Country Water Report. Jordan: Ministry of Water and Irrigation.

UNEP. (2011). Decoupling natural resource use and environmental impacts from economic growth. A Report of the Working Group on Decoupling to the International Resource Panel. Available at: http://www.unep.org/resourcepanel/decoupling/files /pdf/decoupling_report_english.pdf .

UNEP. (2012). Measuring water use in a green economy. A Report of the Working Group on Water Efficiency to the International Resource Panel. Available at: http://www.unep.org/resourcepanel/Portals/24102 /Measuring_Water.pdf .

Wichelns, D. (2010). Virtual water: a helpful perspective, but not a sufficient policy criterion. Water Resources Management, 24, 2203-2219. doi: 10.1007/s11269-009-9547-6.

Wichelns, D. (2013). Virtual Water: Helpful perspective or misleading impression. Global Water Forum Online. http://www.globalwaterforum.org /2013/10/28/virtual-water-helpful-perspective-or-misleading-impressions/ . 